

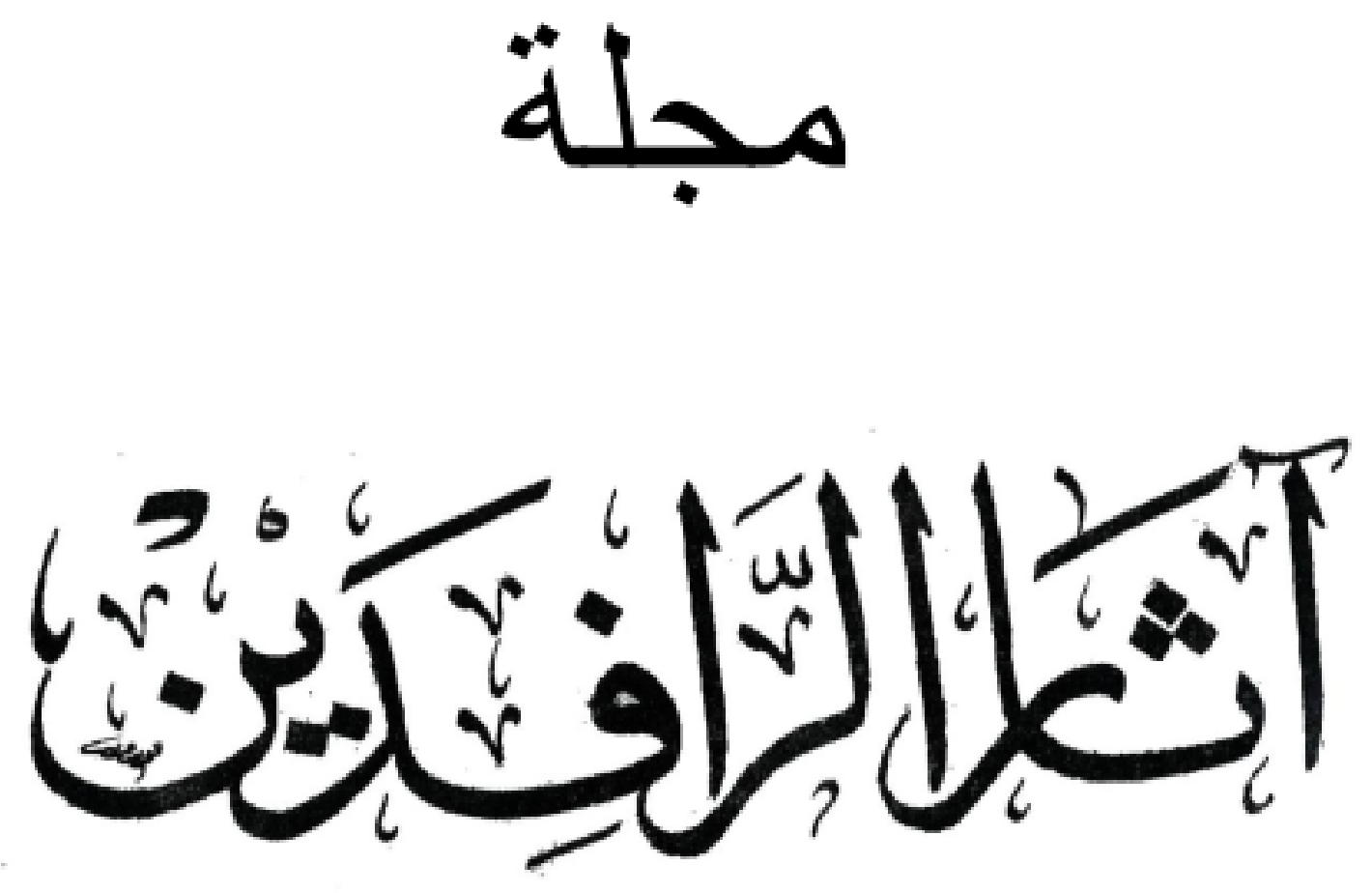

هجلة علمية همكمة تبحث في آثار العراق و الشرق الأدنى القديم تصدر عن كلية الآثار في جاهعة الموصل

E-Mail: uom.atharalrafedain@ gmail.com البريد الاكتروني

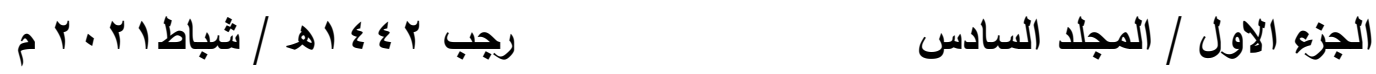

$$
\begin{aligned}
& \text { رقم الايداع في دار الكتب والوثائق بيغداد } \\
& \text { r. I السنة (IVIr) }
\end{aligned}
$$





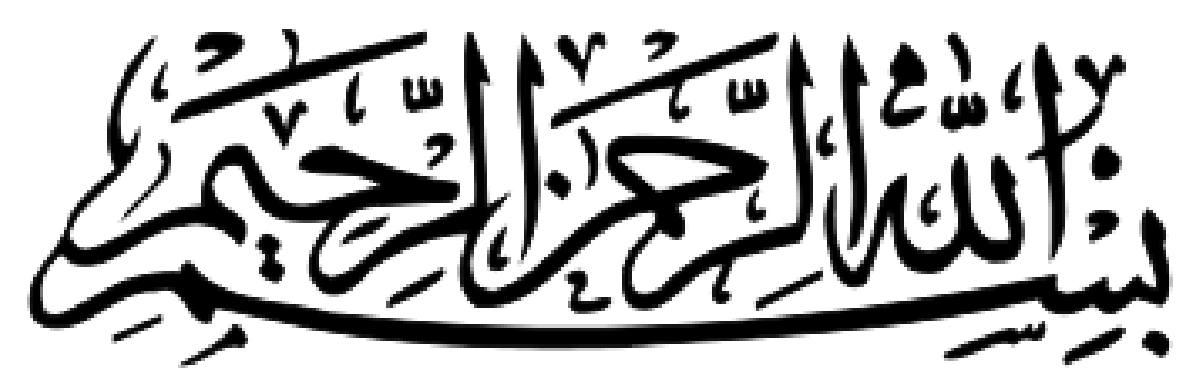





\section{هيأة التمرير}

أ. خالد سالم اسماءيل

رئيس التمرير

أ.م. هسنين حيدر عبد الواحد

الاعضاء

أ.د. اليزابيث ستون

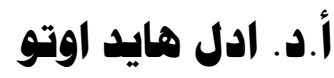

أ.د. والتز سلابيركر

أ.د. نيكولو هاركيتي

أ.د. هديب حياوي عبد الكريم

أ.د. جواد هطر الموسوي

أ.د. رفاه جاسم حمادي

أ.د. عادل هاشم علي

أ.م.د. ياسمين عبد الكريم هممد علي

أ.م.د. فيسان هوفق رشيد

أ.م.د. هاني عبد الغني عبد الله 


$$
\begin{aligned}
& \text { هقوم اللغة العربية } \\
& \text { أ.م.د. همن يميى هصمد }
\end{aligned}
$$

$$
\begin{aligned}
& \text { هقوم اللغة الانكليزية } \\
& \text { م.A. عمار احمد هميمود } \\
& \text { قسم الترجمة / كلية الآداب / جاهعة الموصل }
\end{aligned}
$$

$$
\text { د. تصهيم الغلاف البميلي }
$$




\section{قواعد النشر في هبلة آثار الرافدين}

$$
\begin{aligned}
& \text { 1- تقبل المجلة البحوث العلمية التي تقع في تخصصات: } \\
& \text { • علم الاثار بفرعيه القديم والإسلامي • } \\
& \text { • • اللغات القديمة بلهجاتها و الدراسات الدقارنة. } \\
& \text { الكتابات المسمارية و الخطوط القديمة . } \\
& \text { ه الدراسات التاريخية والحضارية . }
\end{aligned}
$$

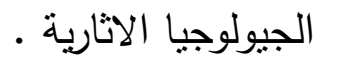

$$
\begin{aligned}
& \text { • تقنيات المسح الاثاري • }
\end{aligned}
$$

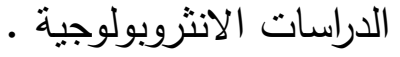

$$
\begin{aligned}
& \text { • الصيانة والتزميم الصنيم }
\end{aligned}
$$

r- تقدم البحوث الى المجلة باللغتين العببية أو الانكليزية .

r-يطبع البحث على ورق (A4)، وبنظام (2010 - word)، وبمسافات مزدوجة بين الاسطر ، وبخط Simplified Arabic للغة العربية، و Times New Roman للغة

$$
\text { الانكليزية، ويسلم على قرص ليزري (CD) ، وبنسختين ورقيتين. }
$$

ع- يطبع عنوان البحث في وسط الصفحة يليه اسم الباحث ودرجته العلمية ومكان عمله

$$
\text { كاملاً والبريد الالكتروني (e-mail). }
$$

0- يجب ان يحتوي البحث ملخصا باللغتين العربية والانكليزية على ان لا تزيد عن (· (1) كلمة.

1-يحتوي ملخص البحث بالإنكليزية على عنوان البحث واسم الباحث ودرجته العلمية ومكان عمله كاملاً والبريد الالكتروني له. V- تضمين البحث كلمات مفتاحية تتعلق بعنوان البحث ومضمونه. ^- ان لا يكون البحث قد تم نشره سابقا أو كان مقدما لنيل درجة علمية أو مستلاً من ملكية

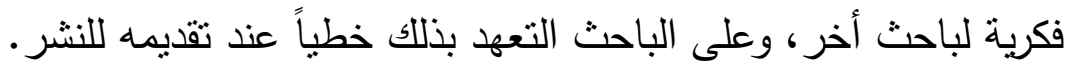
9- يلتزم الباحث باتباع الاسس العلمية السليمة في بحثه. • 1- يلزم الباحث بتعديل فقرات بحثه ليتناسب مع مقترحات الخبراء واسلوب النشر في 
11- لا تتجاوز عدد صفحات البحث عن (ro)، صفحة وفي حال تجاوز العدد المطلوب يتكفل الباحث بدفع مبلغاً اضافياً عن كل صفحة اضافية.

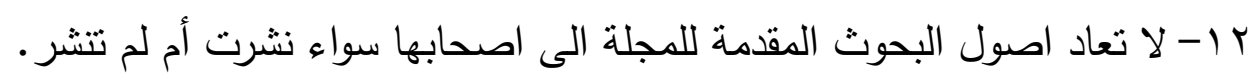
با ا-ترقم الجداول والاشكال على التوالي وبحسب ورودها في البحث، وتزود بعناوين، وتقدم بأوراق منفصلة وتقام المخططات بالحبر الاسود والصور تكون عالية الدقة. ـ ا-تكتب ارقام الهوامش بين قوسين وترد متسلسلة في نهاية البحث. 10-يشار الى اسم المصدر كاملاً في الهامش مع وضع مختصر المصدر بين قوسين في نهاية الهامش.

17 - يتحمل الباحث تصحيح ما يرد في بحثه من اخطاء لغوية وطباعية.

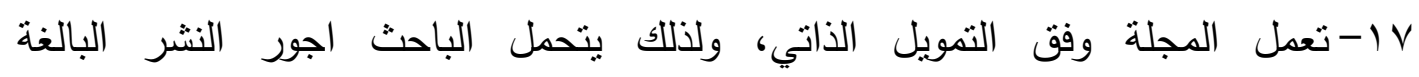

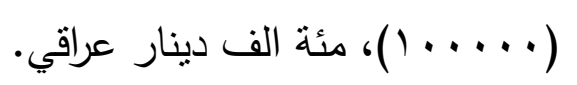

11 ا- يزود كل باحث بمستل من بحثه، أما نسخة المجلة كاملة فتطلب من سكرتارية المجلة لقاء ثمن تحدده هيأة التحرير . 9 ا - ترسل البحوث على البريد الالكتروني للمجلة: uom.atharalrafedain@gmail.com 


\section{ثبت المحتويات}

\begin{tabular}{|c|c|c|}
\hline 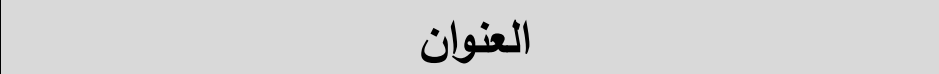 & اسم الباحث & الصفحة \\
\hline 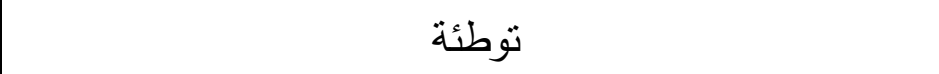 & أ. خالد سالم اسماعيل & 1 \\
\hline من ملاحم ملوك بلاد الرافدين في الألف الثاني والأول قبل & عدي عبدالوهاب النعيمي & $19-4$ \\
\hline "الفِِيْة" في النصوص الأكّدية & أ. د. فاروق إسماعيل & $\leqslant \varepsilon-r)$ \\
\hline هواجس خوف الآشوريين وقلقهم من الأرواح الشريرة & أ.ديم محمد صالح مصطفى صفوان سامي سعيد & $V \cdot-\varepsilon 0$ \\
\hline مدينة سيواس قبل حكم السلاجقة & أ.د. ياسر عبد الجواد المشهداني & $91-v 1$ \\
\hline التتقيات الروسية في منطقة سنجار شمال العراق & أ. أ.م.د. محمد كامل روكان & $11 \leqslant-94$ \\
\hline قالبيوت السكنية من العصر الاشوري الحديث (1) مواقع منتخبة من منطقة مشروع سد مكحول r (1) & أ.م.د. باسمين عبد الكريم محمد علي السامرائي & $1 r v-110$ \\
\hline من الجوامع التزاثية في مدينة سنجار & أ.م.د حيدر فرحان حسين الصبيحاوي نومان الثمري & $17 \leqslant-119$ \\
\hline 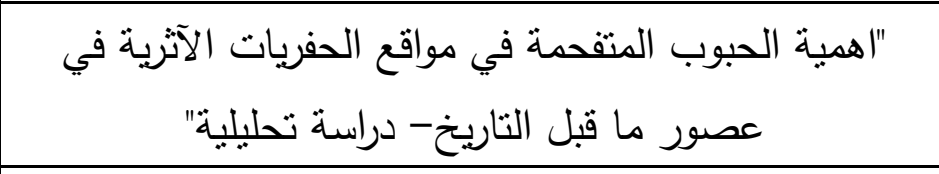 & أ.م.د. حسين يوسف حازم & $110-170$ \\
\hline 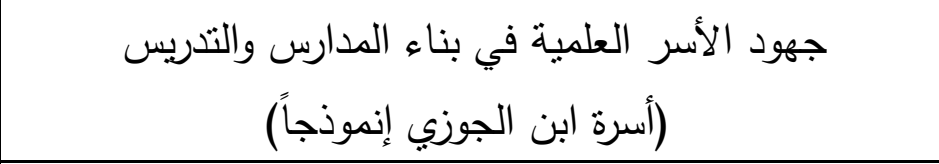 & 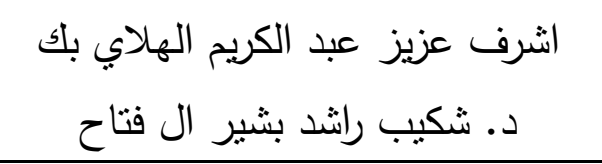 & r) $r-1$ AV \\
\hline دوافع تحنيط الحيوانات عند المصريين القدماء & أ.م.دد وسناء حسون يونس الاغا & 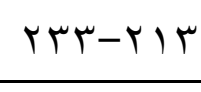 \\
\hline وصولات انجاز اللبن من مدينة بيكاسي " تل ابوعنتيك" - " & د.آرام جلال حسن الهموندي & rTI-rTO \\
\hline نصوص اقتصادية غير منشورة من سلالة اور الثالثة & م.د مهند خلف جمين الثمري & rV9-rฯr \\
\hline الثياطين والأرواح الثريرة في العراق القيم في ضوء النصوص المسمارية & 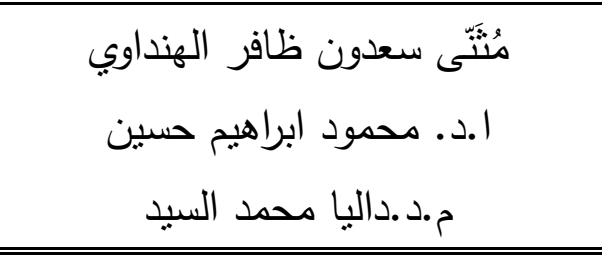 & $r \cdot r-r \wedge l$ \\
\hline
\end{tabular}





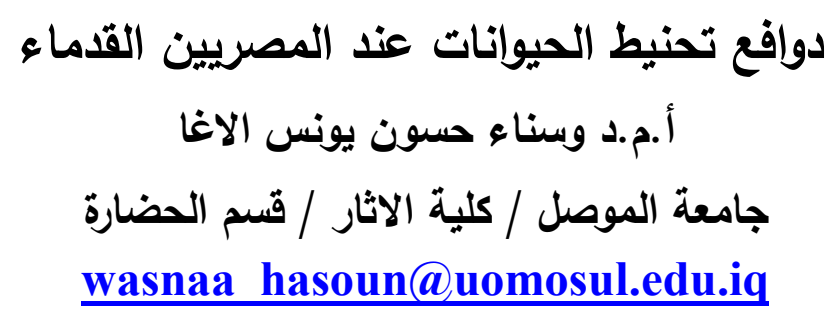

\title{
Motives behind the Mummification of Animals by the Ancient Egyptians
}

\author{
Asst. prof. Dr. Wasnaa Hasoun Younis al-Aghaa \\ University of Mosul- College of Archaeology \\ Department of Civilization
}

\begin{abstract}
:
The ancient Egyptians mummified animals for they belief that they were of a sacred status. Despite that hadn't been worshipping those animals, they sanctified them for their symbolic significance in which they believed would bring them closer to the deity. Even though, those animal deities had been nothing but embodied appearance or a symbol of divine powers, but the ancient Egyptians believed mummification would fill the place with blessings, protection and they would avail of them in the afterlife as food and enjoyment as it was the case in the earthly life.
\end{abstract}

Keywords: Mummified, Deities, Sanctify, Animals, Worshipping.

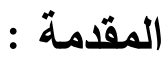

بدأ الانسان المصري القديم تدجين الحيوانات من اجل استخدامها كقوة للزراعة ، فضلا

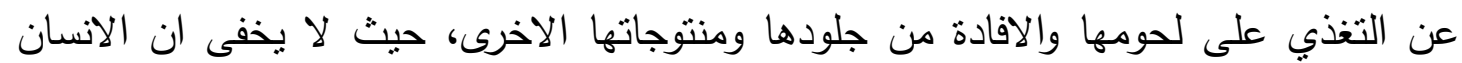


المصري القديم قد اعتمد في غذائه على اللحوم التي يحصل عليها من الحيوانات التي كان يصطادها كالطيور والاسماك والحيوانات البربة الاخرى وبسبب المعتقدات الدينية التي كانت مرتبطة بالحيوانات كثيرا لذلك حنطوا الملايين منها لاعتقادهم ان الحيوانات ذات مكانة مقدسة، ففي اغلب الاحيان كان أمون كبير الالهة في مصر القديمة يصور على هيأة مخلوق برأس كبش فيما كان يصور انوبيس اله الموتى على انه ذو رأس حيوان ابن اوى اما حورس اله السماء فقد هياه كان يظهر عادة برأس صقر . ويبين الدكتور علاء شاهين عميد كلية الاثار سابقاً ويقول انه من ضمن العقيدة المصرية القديمة ان الاله يتجسد في شيء معين سواء انسان او حيوان او خليط بينهما منها ولذلك حصل الحيوان على مكانة خاصة ونوع من التقدير فالحيوانات كانت تمثل شيئين للمصري الاول انها كانت عماد اقتصاده والثاني رمزا دينيا يعبر عن الاله ولذلك فان الرسومات التي كانت على جدران المعابد تعبر عن شكل من اشكال الحياة التي كان يعيشها ويحرص على رسم جميع مناظرها على جدران المعابد ليلتمس بها مظاهر الحياة الدنيا في حياة البعث وكان يرسم الحيوانات العادية التي يستخدمها في يومه، اما الحيوانات التي تكون رمزا للاله فكان يحرص على تحنيطها ووضع جثنها في توابيت ومقابر حتى وصل الامر لحد عمل مقابر خاصة لهذه الحيوانات التي تتجسد فيها روح الالهة (1). وما سبق ليس سوى بعض الامتلة التي تظهر الاهمية التي اكتسبتها الحيوانات في مصر القديمة فقد كان لهذه الكائنات وضع مرموق وذو مسحة الهية، وعلى الرغم من اضفاء هذه الهالة المقدسة على تلك الحيوانات كان يجلب لها الاحترام والتوقير في حياتها، فان ذللك ربما كان يؤدي كذلك الى قتلها وتحنيطها، لذلك كان من الممكن استهداف اي حيوان او كائن من الكلاب والقطط والكباش والتماسيح والقردة وصولا الى الطيور بما في ذلك طيور الباز والصقور وكذلك طيور ابي منجل وحتى القوارض والثعابين كانت من بين ملايين الكائنات الحية التي جرى تحنيطها في مصر القديمة، ومنذ للك الحين جرى استخراج بعض هذه المومياوات بالفعل ولكن يعتقد ان ملايين اخرى لا تزال قابعة دون حراك في سراديب الموتى الواقعة تحت الارض في ارض مصر من دون ان يمسها احد لفترة تزيد على الفي عام. التحنيط : مصطلح عام يعني الحفاظ على الجسم من البلاء والتلف، والجسم المحنط يسمى مومياء(r)، وكلمة التحنيط هي كلمة عربية اشتقت من كلمة الحنوط ويقصد بها مواد الحفظ التي مني كانت لها رائحة عطرية منل المسك والعنبر والكافور (r)، وان اول دليل مؤكد على التحنيط يرجع

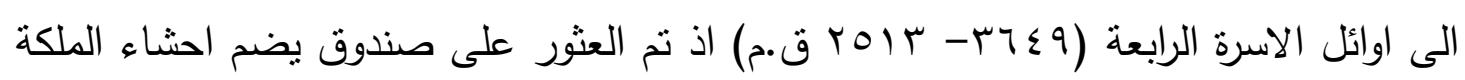
حتب حرس والدة الملك خوفو مغمورة في سائل النطرون وكان يمارس لاى العائلة المالكة 
والكهنة وكبار الموظفين والطبقات الغنية ولم يعد استعماله الا بعد مرور مدة طويلة حتى عرفوا

ممارسة الطرائق الرخيصة والبسيطة والمناسبة للفقراء(؛). ونظرا لقدسية الحيوان لديهج حاولوا حمايها والحفاظ عليها، وقدس المصري القديم الحيوانات لرمزيتها ولم يكن يعبدها بل كانت في نظره رموزا وصفات للإله الخالق وقد حاول الوصول بفطرته الى التقرب الى الاله عن طريق هذه الرموز المادية الملموسة (الحيوانات)، فعندما تموت احدى تلك الحيوانات تؤخذ للتحنيط حتى صار في نهاية العصور المصرية تحنط على انواع الحيوانات من الحشرات الصغرى كالخنافس الى التماسيح العملاقة ولكن كانت تعد كهدية للاله، وان تحنيط الحيوان المقدس عموما يتم في ثلاث خطوات هي: ا - حقن الحيوان بزيت الارز من فتحة الثرح. r- تجفيف الجسد وبداخله الزيت. r- سحب الزيت بعد انتهاء فترة التجفيف. وكانت هذه الخطوات مكلفة للغاية ومن المعروف ان هذه الحيوانات بعد تحنيطها كانت تذفن في قبور مخصصة لها وتقام لها طقوس الدفن منث الانسان (0)وقد عثر في الارض هذه المصرية على العديد من الجبانات(؟) التي خصصت للحيوانات منل جبانات الكباش بمدينة اسوان، وفي منطقة تونه الجبل بالمينا عثز على مئات من السراديب التي تضم مومياوات من

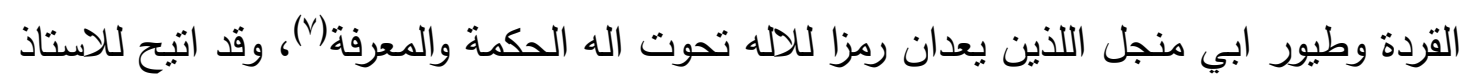
سامي جبرة المدير السابق لمعهد الاثار المصرية لجامعة القاهرة، اثثاء قيامه بكثوفه المعروفة في منطقة تونه الجبل ان يكثف عن سراديب سفلية نحتت في الصخور لبعض كيلومترات خصصت لدفن القرود وطائر ابو منجل (رمز عبادة تحوت).

اهم المواد المستخدمة في تحنيط هذه الحيوانات: 1- القلقونية : وهي مادة صفراء لامعة داكنة نوعا ما اثتتت التحليلات انها مادة راتتجية ذات رائحة عطرية تحضر من اشجار صنوبرية تلك التي تتمو في سوريا وسواحل فينيقيا وتحضيرها يتم عن طريق عمل ثقوب في الاشجار ثم تجمع العصارى في اوان ويبخر الجزء السائل(^)، ويبقى الجزء الصلب (وهو القلفونية)، ومن خواص هذه المادة سهولة ذوبانها في بعض السوائل فتصبح محلولا ذا قوة لاصقة وهي تتفكك عند تسخينها فتكون سائلاً للصق وهون اللفائف والضمادات. ץ- الزفت: من الاصل الخشبي وهو قطع سوداء متربة السطح ذات رائحة قطرانية تلين عند التسخين وتتسامى مرسبة على جدران انبوبة الاختبار مادة راتتجية صفراء وهذه المادة تحترق بلهب لامع ذي دخان كثيف ويحضر القطران النباتي بطريقة التقطير الاتلافي او الحرق 
بمعزل عن الهواء لاخشاب اشجار العائلة الصنوبرية وتحوي المادة كثيرا من المواد المطهرة

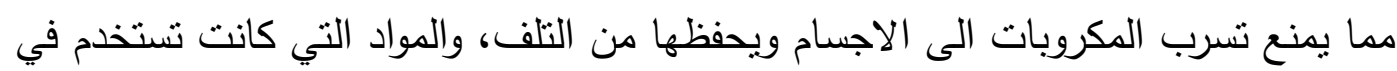

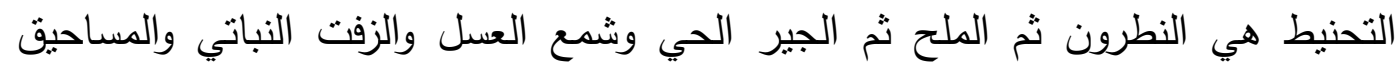

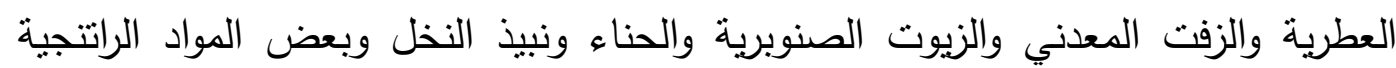

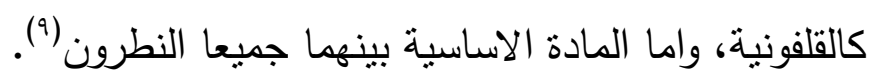

الحيوانات التي كانت تربى لمساعدة الانسان وحمايته: 1-الكلب (ابن اوى) : استؤنس الكلب في مصر قبل عصر الاسرات ودفن بالقرب من صاحبه،

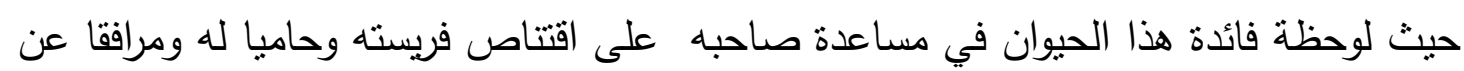

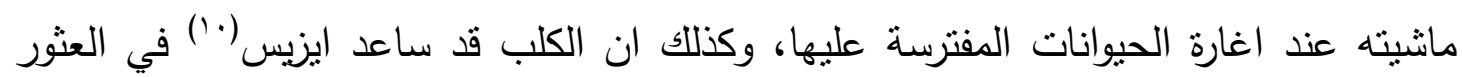

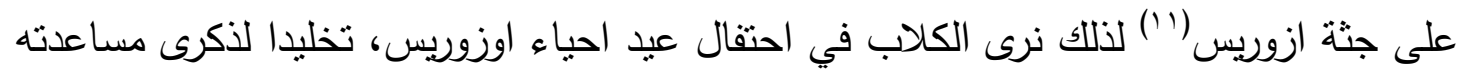
لها، وأيضا كان نباح الكلاب يعطي انشارة تتذير بالخطر ، كما كانت الكلاب تشتخدم منل الاسود في ساحة القتال، فضلا عن ذللك كانت هناك كلاب تستخدم للهو والتسلية وتكون دائما مرافقة لاصحابها، وهذه الكلاب تلاحظ كثيرا على اللوحات المأتمية وظلت الكلاب مع الاسر لات لات تفارقها،

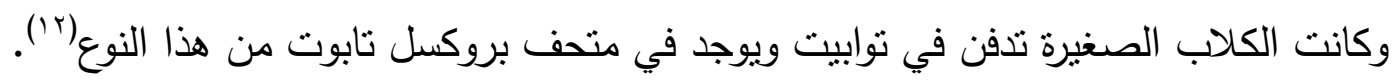

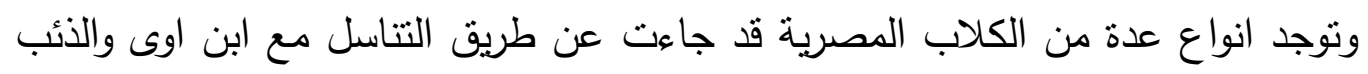

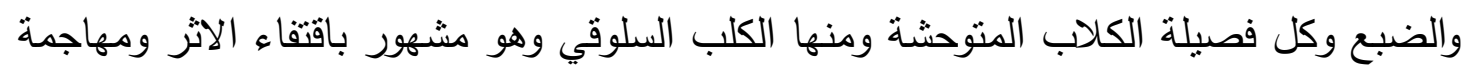

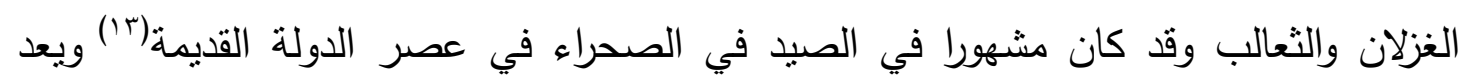
انوبيس كما في الثنكل (1) هو رئيس آلهة الموتى، وان رمز الالهة قد اعثبر ككلب فان الدئل الداثل

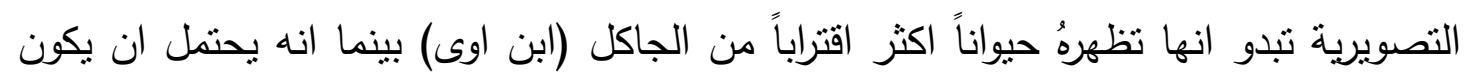

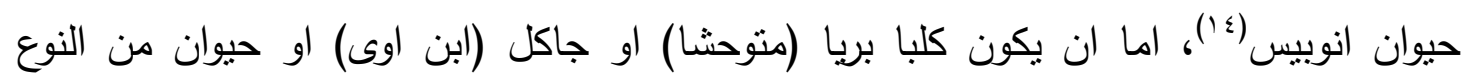

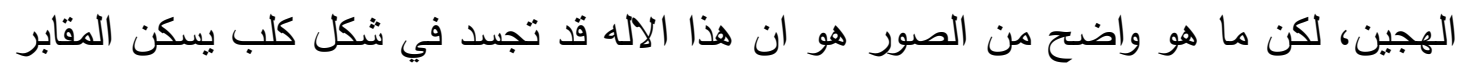
على حافة الصحراء وانه قد اثنترك مع الجبانة منذ العصور المبكرة.

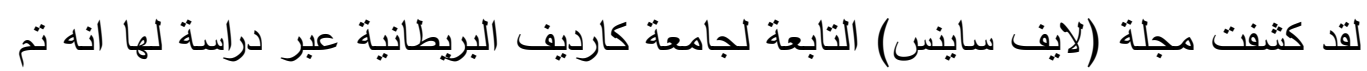
العثور مؤخرا على مقبرة جماعية لمومياوات لثمان ملايين كلب محنط كما في الثنكل (Y) اثثاء

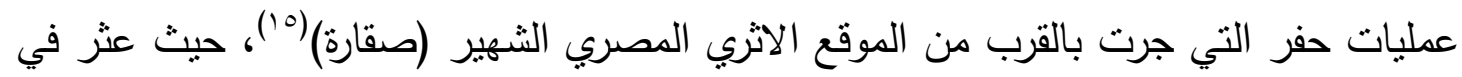

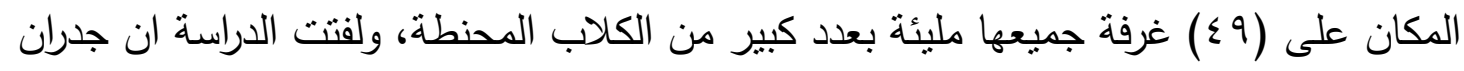

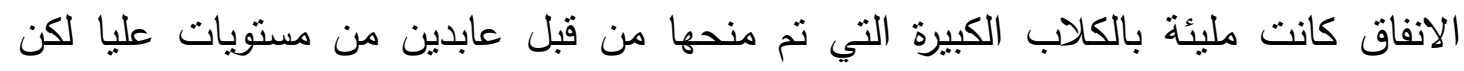
الاكوام التي داخل الانفاق كانت مختلفة حيث وجد الباحثون انها عبارة عن عظام جراء صناء صغيرة تم قتلها عقب ولادنها فورا. 
واظهرت هذه الدراسة ان عالم الاثار بجامعة كارديف (بول نيكلسون) تتبع من خلال دراسته الخريطة التي سماها (جاك دي مورجان) وحدد بها سراديب كمدافن للكلاب في منطقة

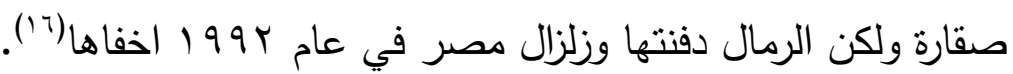
وكذللك اكد احد علماء المومياوات المصريين ويدعى (احمد صالح) على ان موضوع تحنيط الحيوانات في مصر القديمة هو شهير جدا، وبحسب العالم المصري اعلاه فان مؤرخي الاغريق اعتقدوا في السابق ان قدماء المصريين كانوا يعبدون الحيوانات، وقد قام بدحض هذه

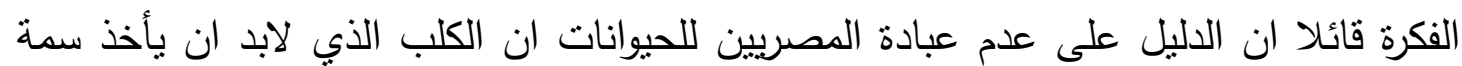

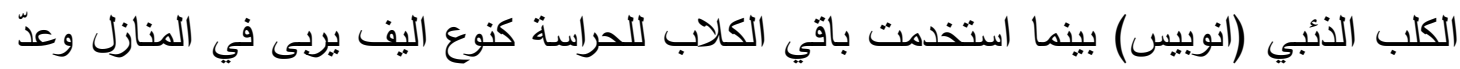
العالم المصري ان عدد الكلاب المحنطة المعلن قد يكون مبالغ فيه حيث لم تظهر الدراسة كيفية حساب الرقم وعلى ما يبدو فانه يدور على رقم تقديري او تقريبي. وبحسب الدراسة أيضا كان

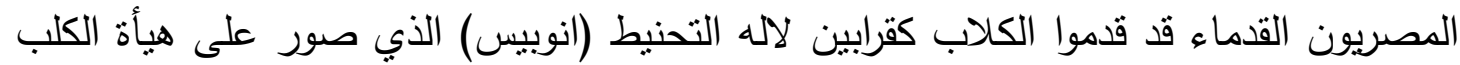

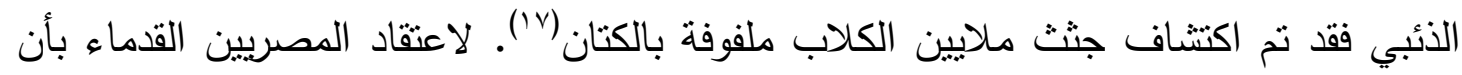

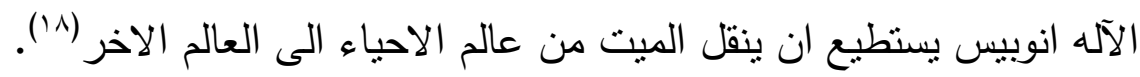

\section{r ب القطــة}

تعد القطة حيوانا مدللا عند الدصريين القدماء ، حيث كانوا يربون نوعين من القطط، نوع عظيم الجسم وهو الذي يمثل الالهة (باستت) كما في الثنكل (r) ونوع اخر صغير مستأنسة، ولم تحظ القطة بالتبجيل كما هي في مصر القديمة، وفي الواقع كان عصرا ذهبيا من تاريخ هذا الحيوان هو تقديسه وتأليهه. لقد ظهرت عبادة القطة في احدى الفترات الاولى من التاريخ المصري القديم، حيث نم

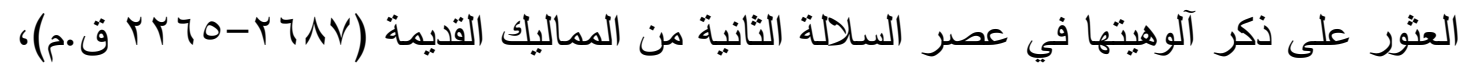

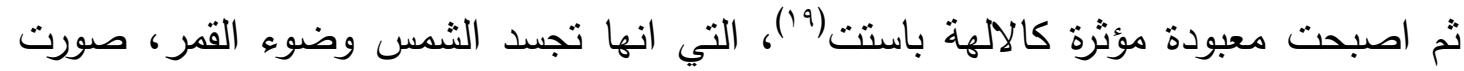

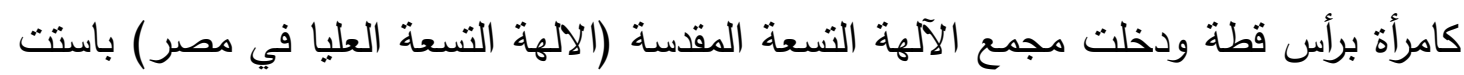
ربة الفرح والحب وجمال الانثى والخصوبة والمنزل(·r).

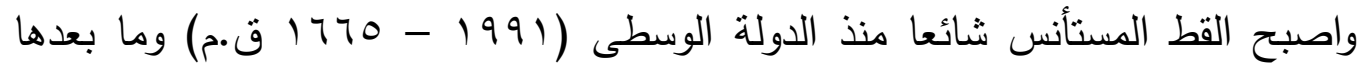
وتثاهد القطة مستخدمة في صبد الطيور وذلك للقبض على الطيور التي اصطادها سيدها، او

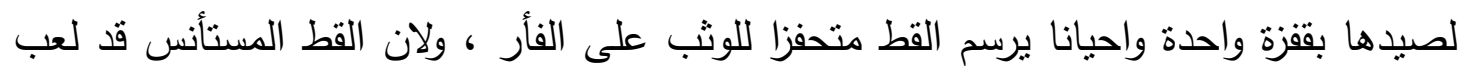

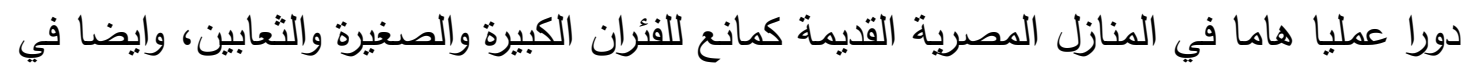
استخدامه في الصيد في مستتقعات البردي لقد تكرر(بآ) رسمه في رسوم مقابر الدولة الحديثة

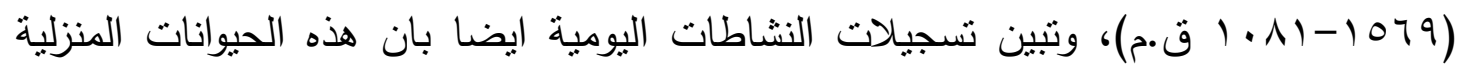


تظهر جالسة بين ارجل مقعد صاحب المقبرة وعلى مايبدو ان هذا تقليد متبع حيث يخص احد

الحيوانات بهذا الاظهار والتدليل(rr).

وعلى الرغم دن ان اضفاء هذه الهالة المقدة على نللك الحيوانات عند المصربين القدماء

كان يجلب لها ايضا الاحترام والتوقير في حياتها وأيضا كان يؤدي كذلك الى قتلها وتحنيطها لمساعدتهم بالحياة الاخر بحسب اعتقادهم، اذ تلقت اغلب القطط التحنيط نفسه بعد الموت كالبشر، ففي عام 111 ام اكتشف فلاح مصري قبرا كبيرا يضم نحو (•^) الف قطة محنطة

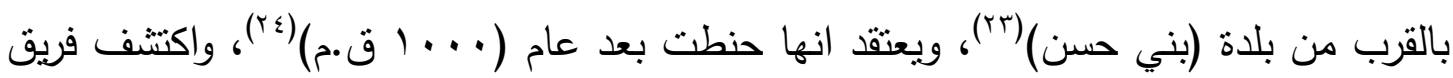
تتقيبي ان بعض هذه المومياوات وبرأي الباحثة (ليديا ماكنايت) من جامعة (مانشستر) والتي فحصت المومياوات المعروضة الان بالمتحف بالاشعة السينية كما في الثكل (ع)، ان هناك "محتويات منتوعة بداخل المومياوات على الرغم من انها تبدو من الخارج منتابهة تماما"، وان عملية التحنيط التي كان بتبعها المصريون القدماء لتحنيط تلك الحيوانات كانت تقتصر على الخطوات الاساسية لعملية التحنيط فحسب، فعلى سبيل المثال لم تكن عملية تحنيط الحيوانات تشمل على نزع الاعضاء الداخلية من اجسادها كما كان يحدث مع البشر وقد عولجت هذه المومياوات بمزيج من الراتتج المستخلصة من الاشجار وشمع العسل وهو مزبج يعمل كغلاف مضاد للجراثيم والبكتريا ويغطي الحيوان المراد تحنيطه وتشكل هذا خطوة مهمة لوقف عملية تحلل المومياوات، وبعد اتمام هذه العملية كان القائمون على عملية التحنيط يكتقون بلف المومياء ليس اكثر بحسب ماذكرته (ماكنايت)، وان بعض هذه المومياوات كانت تحتوي داخل امعائها على بقايا واضحة لاخر الوجبات التي التهمتها هذه الحيوانات قبل ان تهلك، واشارت كذللك الباحثة الى أن الحفاظ على بقايا ما كانت تحتويه الامعاء يعني انه كان يتعين على القائمين على عملية التحنيط تفريغ هذه الامعاء من السوائل وتجفيفها بسرعة شديدة وهو ما بحول دون حدوث عمليات تحلل قبل ان تحفظ هذه البقايا(ror).

وكان الغرض من تحنيط القطط ارسالها الى العالم الاخر كقرابين او رسل موجهة مباشرة الى الاله، وان الفكرة وراء ذللك كانت تتمثل في انه بالامكان ان يستجيب الاله للصلوات والدعوات اذ ما كانت برفقة نذور في شكل حيوانات محنطة، وكان المصريون القدماء يضعون رسما للحيوان الذي سيتم ارساله كنذر وذللك حتى يتسنى للالهة التي سترسل اليها والتي تصور على شكل حيوانات بدورها ان تتعرف عليها(بr). ومن الجدير بالذكر عن اهمية القطط عند المصريين القدماء ما ذكره هيرودتس عن نشوب حريق في احد المنازل فوقف الجيران وامسكوا بايديهم صفا حول هذا المنزل حتى يمنعوا القطط من الدخول في النيران فتحترق، وعلى الرغم من ان هيرودنس دون هذه القصة لاندهاشه من عدم اهتمام المصريين بانقاذ المنزل المحترق 
واصحاب هذا المنزل الا ان هناك مبالغة في هذه القصة، لكنها من جانب اخر تدلل على حب المصريين القدماء واهتمامهم (rV) ولن.

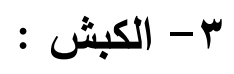

استخدمت الخراف بقيادة كبشهم لتدوس الحبوب التي بذرت للزراعة في الطمى الذي تركه

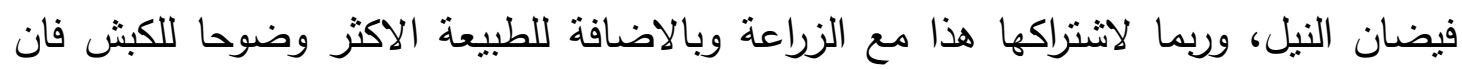

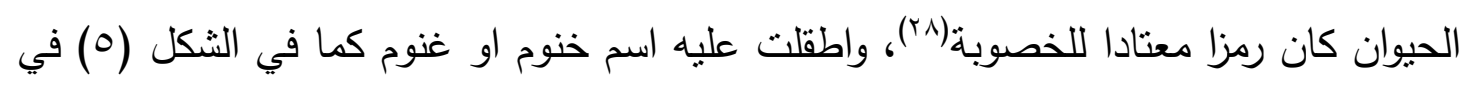

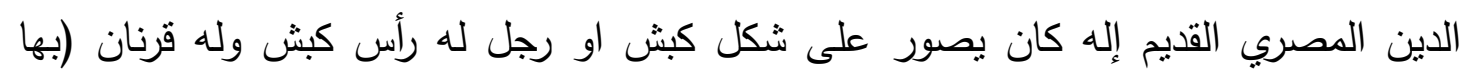

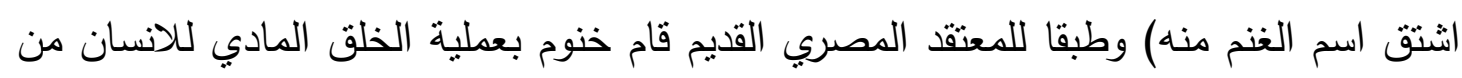

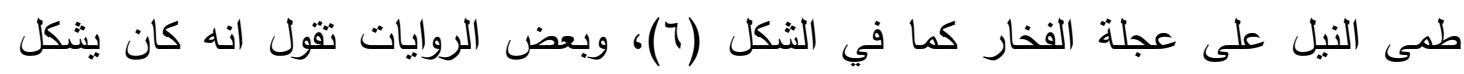

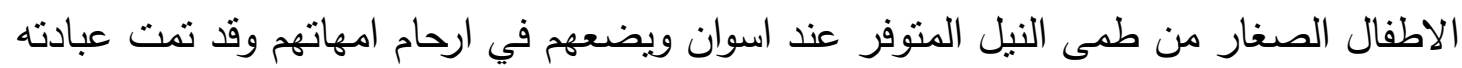

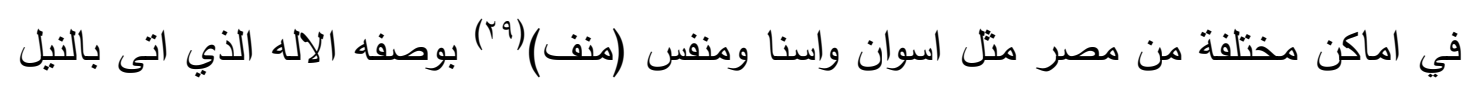
ليقيم الحياة على ضفافه (·r). كان يوجد في مصر القديمة، نوعان من الضأن يعرف الاول منهما بالكبش الوثاب الكبش

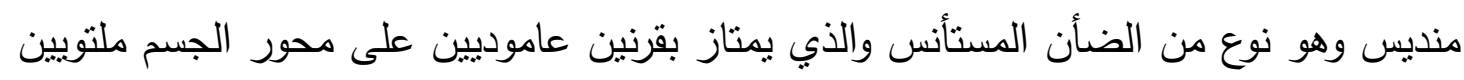
على شكل حلزوني ، كما يمتاز بطول قدميه وذيله وله عفرة عظيمة تغطي مقدمة العنق واذناه

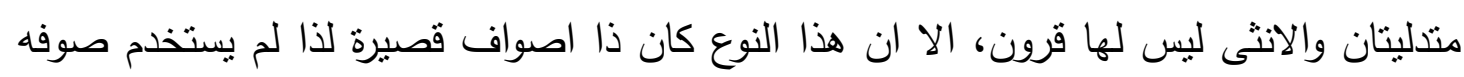

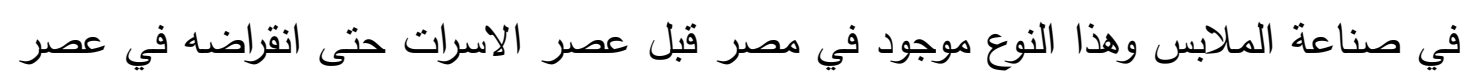

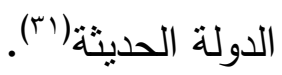

واما النوع الثاني من الضأن فبدأ تاريخ وجوده في مصر القديمة منذ عصر الاسرة الثانية

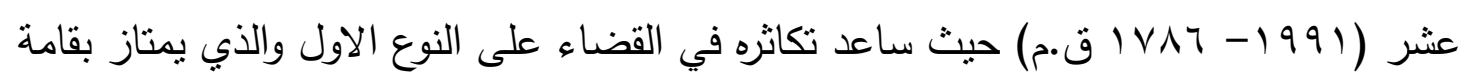

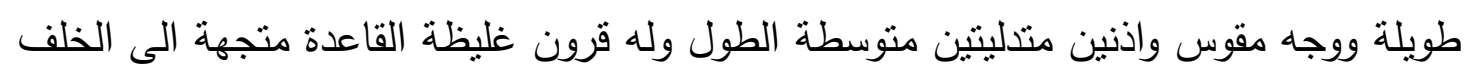
ثم تتحني الى الامام، كما له ذيل طويل ضخم اللية وذو صوف قصير ايضا ولم يستخدم هذا

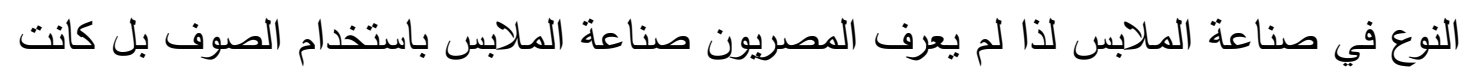

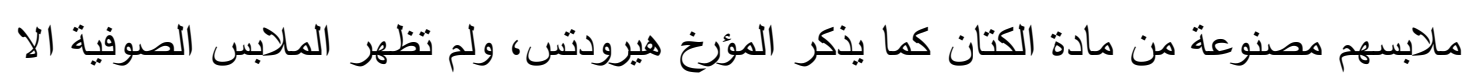
في العصر الاغريقي، ويعزى بعض الباحثين ان صوف الغنم الذي عثر عليه في تل العمارنة

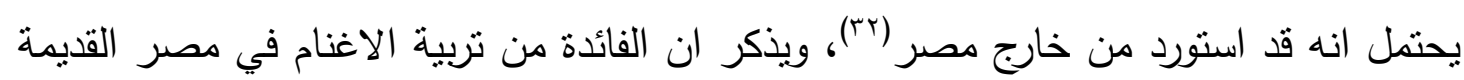

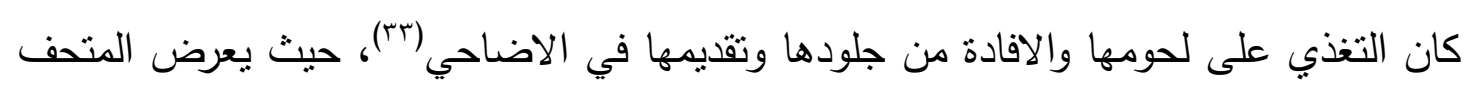

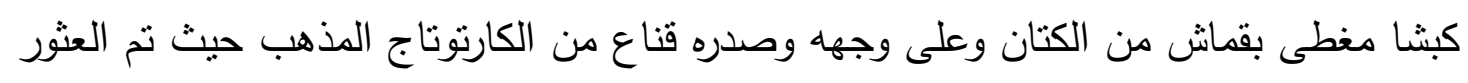

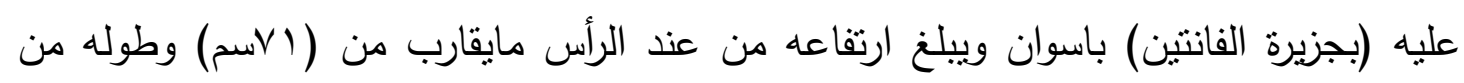


الذيل حتى الصدر مايقارب من (ادسم) والمعروف ان روح الاله خنوم في العقيدة المصربة تقصت بالكبش ذا القرون الاققية المسطحة، والدليل على ذلك ما ذكره احد النصوص المدونة بالكتابة الهيروغليفية حيث يقول مانصه (يا اوزير روح الاله العتية الخاصة بخنوم) وهذا النداء للاله اوزير روح الاله خنوم التي تسكن في الكبش(عَ).

$$
\text { : ع الدواب }
$$

البقة

استأنس المصريون القدماء الابقار كونها حيوانا اليفا ، حيث افادوا من قوتها في الزراعة ومن منتوجاتها في التغذية ، فضلا عن انها تتميز بالمقدرة على الاخصاب والتتاسل لذلك اتخذوها كألهة مميزة وقدسوها ورمزوا لها بالالهة حتحور آلهة الخصب والجمال وتسمى البقرة بالهيروغليفية (حمت Hemet) (ro)، وكانت لها اهمية كبيرة في الاعمال الزراعية فضلا عن انتاجها للحليب واللحم وجلدها السميك وقدتها على التوالد والانجاب وشكلها المميز حيث عرف المصريون القدماء انواعا عدة من الابقار كالابقار ذات القرون القيثارية والابقار ذات القرون الهلالية وذات قرون الزاوية وذوات القرون القصيرة وعديمة القرون (זr). وتتم عملية حلب الابقار على الرجال حصرا، وان البقرة عبدت في مناطق عدة في مصر

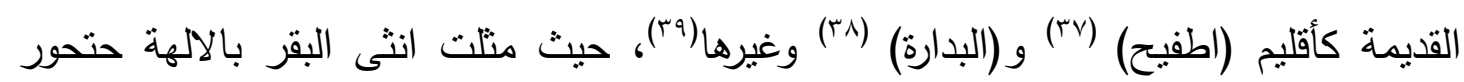

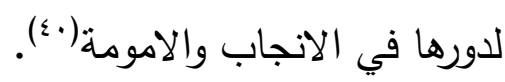

يبين الدكتور محمد بكر استاذ التاريخ الفرعوني مؤكدا ان هنالك من الملوك من احتفى التى بهذه الحيوانات بوصفها ذات قوة سحرية خارقة وهما البقر والثثران وذلك ما دفعهم لاحترام هذه الحيوانات وتقديسها وتحنيطها ودفنها معه في المقابر • ومن هنا كانت فكرة تحنيط الحيوانات لتتقل هذه الرموز والقوى الى العالم الاخر مع المصري('ミ)، اما الاسطورة التي تقوم عليها عبادة البقر هي قصة الربة حتحور والتي بعني اسمها مكان استقرار حور او حورس وهي توصف بانها ابنة الاله رع وكانت هي آلهة السماء والحب والجمال والمتعة وصورت كبقرة او امرأة يزين رأسها(r\&) قرص الثمس بين قرني بقرة كما في الثكل (V) ودائما ما تمنلاك اذنا بقرة، وكانت اهم معابدها في دندرة (الصعيد) حيث سميت هناك بحتحور العظيمة ، سيدة دندرة ، راعية السماء ملكة الالهة ابنة رع(r) المبجلة وكانت الربة حتحور تصور كألهة من الهة الموتى وصارت سيدة الموتى ونم تصويرها في المعابد الجنائزية على هيأة شجرة الجميز (ء؛)، لكي نرعى الموتى وتعطيهم ما يأكلوه ويستظلوا به في رحلتهم الى العالم الاخر(0؛)، واكد احد علماء المومياوات المصريبن احمد صالح ان المصريين القدماء لم يعبدوا هذه الحيوان ودحض فكرة العبادة قائلا ان الدليل على عدم عبادة المصريين للحيوانات هو اختيارهم بقرة محددة تعبر عن صفة الحنان 
للاله واطلقوا عليها اسم الاله حتحور ، بينما باقي الابقار ذبحوها واكلوا لحومها واستخدموها في الحقل (乡i)

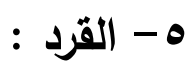

كان الدصريون القدماء يستأنسون نوعين من القردة منذ عصر الدولة القديمة النوع الاول

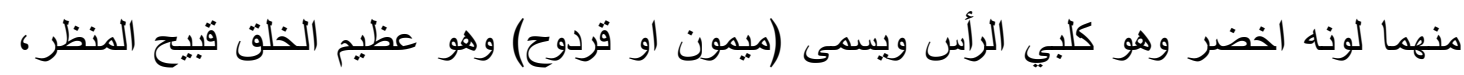

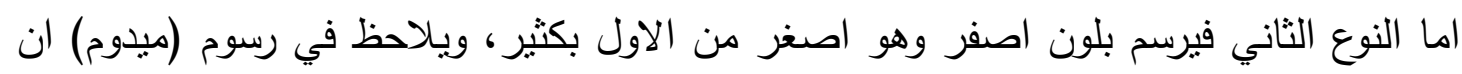

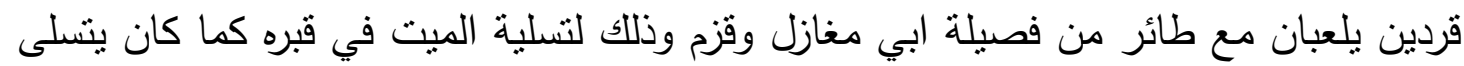

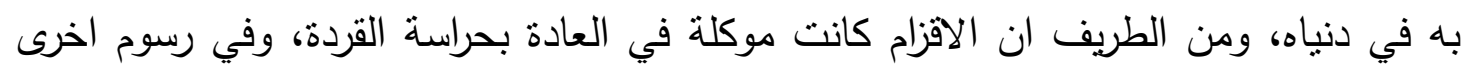
يشاهد القرد مربوطا في كرسي سيده بطوق احمر حول وسطه، وفي لوحات اخرى يظهر القرد

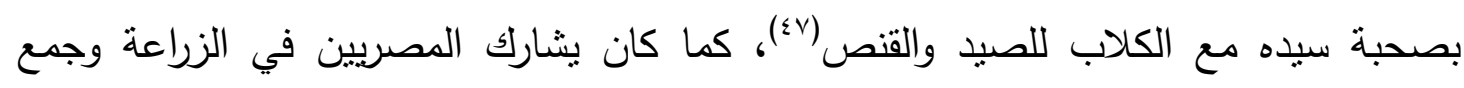
المحاصيل والفاكهة والرقص والموسيقى.

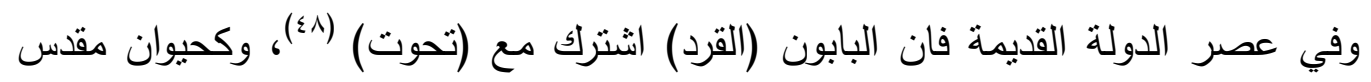

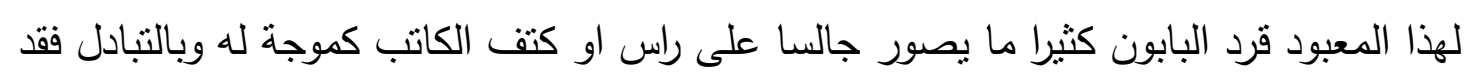

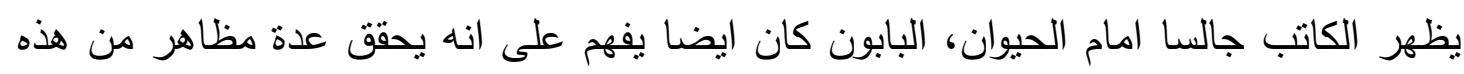

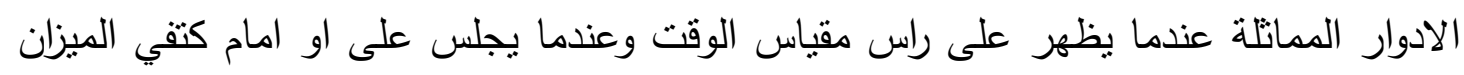

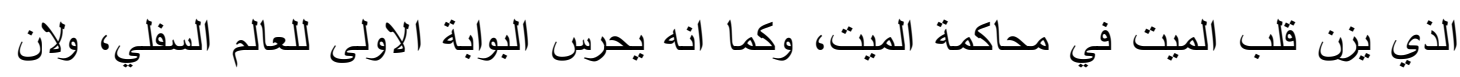

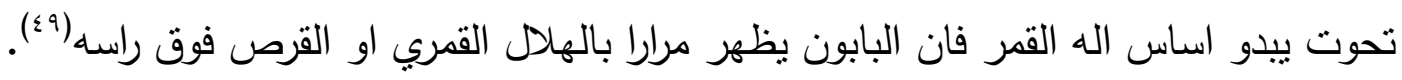
وثمه العلاقة بين البابون والثمس كانت لصياحه او تهليه لطلوع النهار او ممارسة بتدفئة

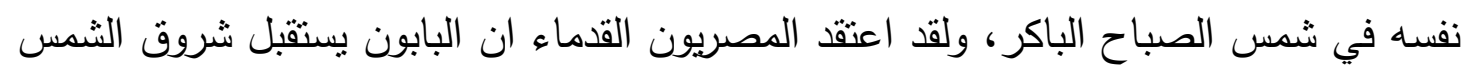

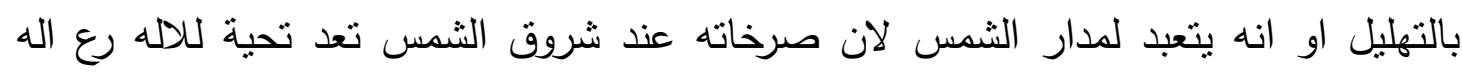

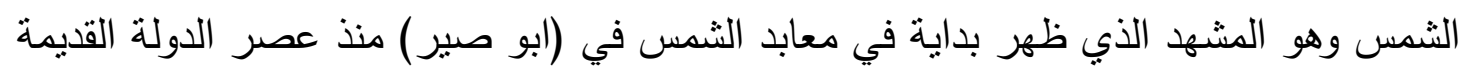

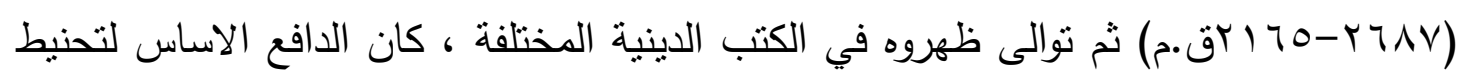

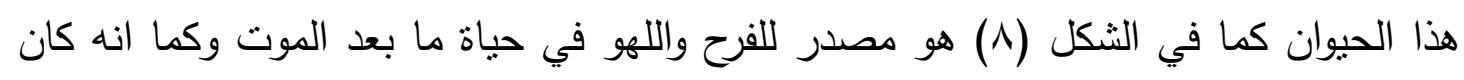

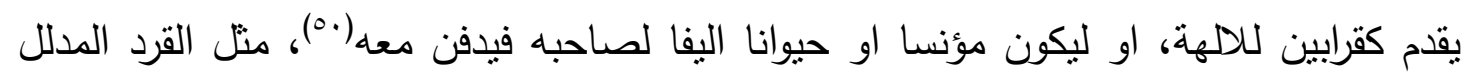

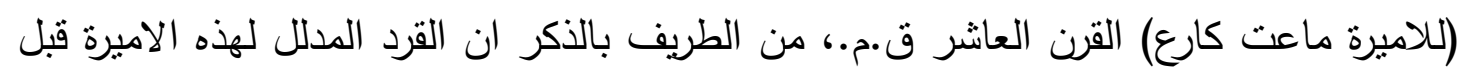

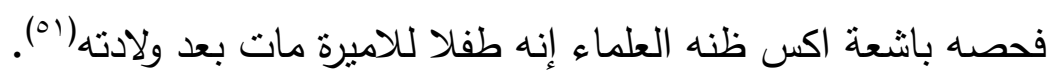

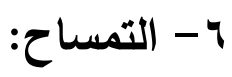

(سوبيل ، او سوبك ، او سبك ، كما يمكن نطق اسمه سبك ، سوخت ، سوبكي) كما في

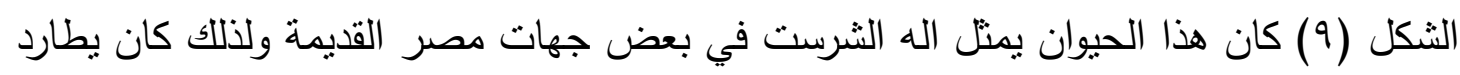


فيها(م)، وفي جهات اخرى كان يعبد بصفته الاله (سبل اله الخير) فكان يقس كما كان الحال

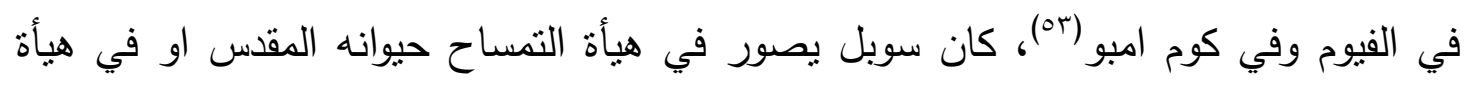

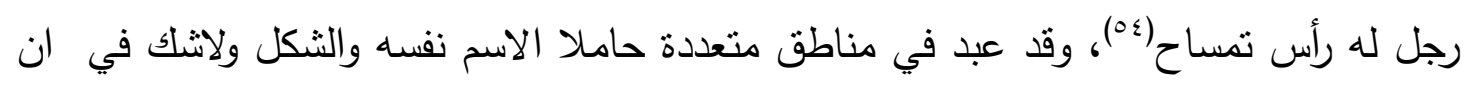

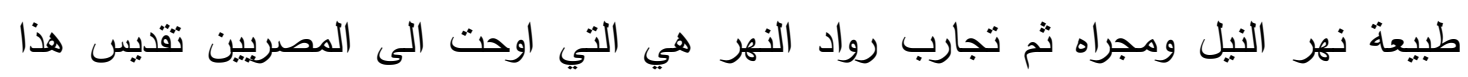
الحيوان وهكذا ادرك اولئك الذين يعملون في مجرى النهر من ملاحيين وصيادين باسه (00.

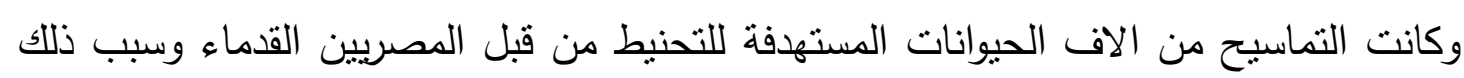

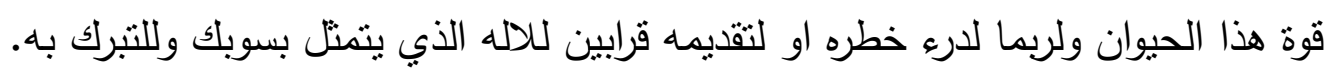

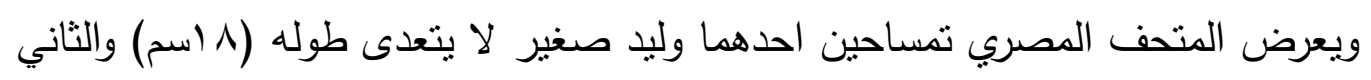

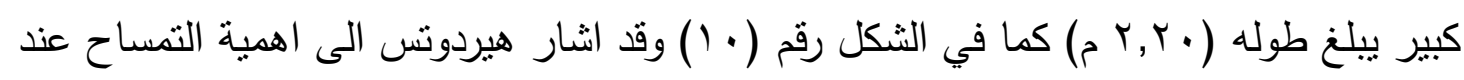

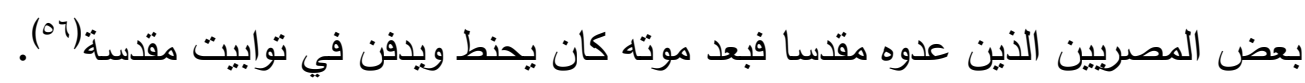

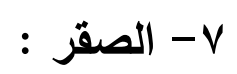

كان يمنل بالاله حورس كما في الثكل (1) (1)، يصور كصقر او رجل له راس صقر وهو

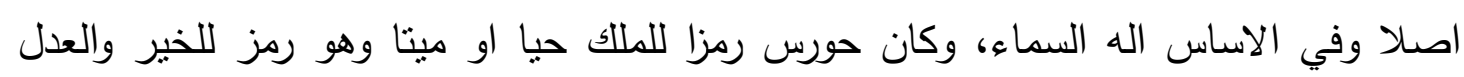

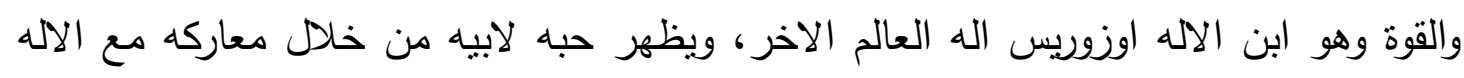

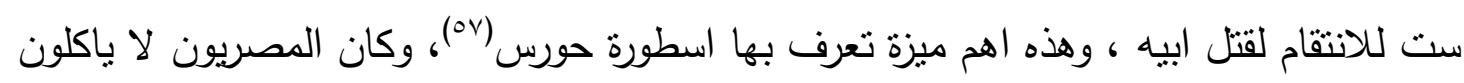

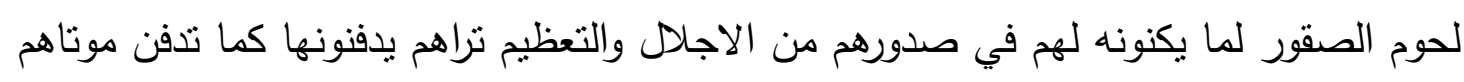

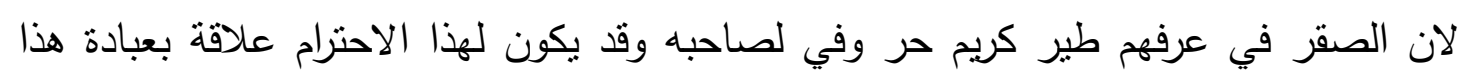

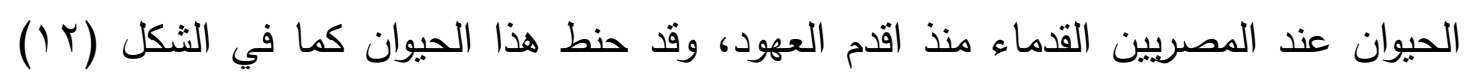

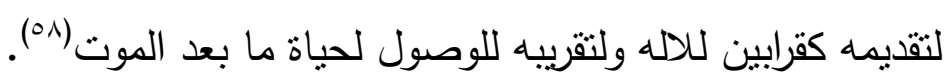

$$
\text { - ابو منجل: - n }
$$

اله قمري في الاصل ثم اصبح من اقوى الالهة المؤثرة، اله الحكمة والكتابة، وهو مخترع

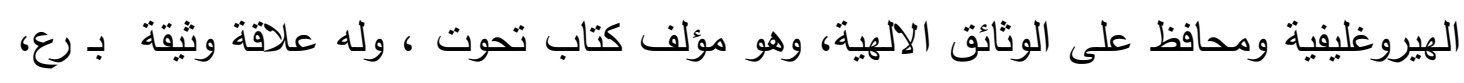

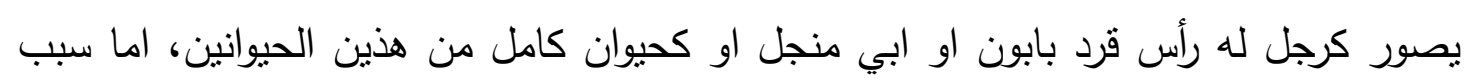

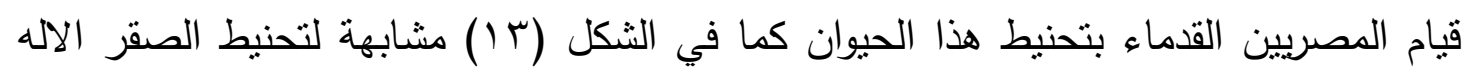

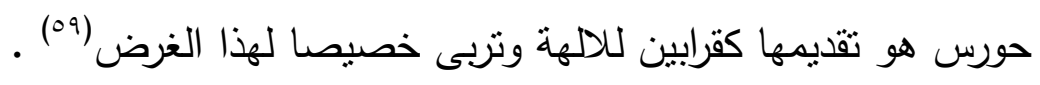


استنتاجات

تحنيط الحيوانات :

حنط المصريون القدماء الحيوانات لاسباب مهمة :

1- يعتقد المصريون القدماء ان الحيوان منل الانسان عندما يموت يحدث انفصال بين الجسد

$$
\text { والروح وسوف ثرجع الروح يوم الدفن الى الجسد. }
$$

r- الحيوان المحنط كان يقدم بوصفه نوعا من النذور للالهة في المعابد.

r- حب المصربين لبعض الحيوانات هنالك، وتحنيطهم لها واحتفاظهم بها معهم في العالم الاخر مثل القرد المدلل لاميرة ماعت.

ع - ان عناية المصربين القدماء بتربية حيواناتهم تحتم علينا ان نبحث في اصل عقائدهم الدينية فقد كانوا يقدسون كثيرا من الحيوانات التي تتصل بجباياتهم وهم لم يقدوا الحيوان بذاته انما قدسوا فيه سرا من اسرار الخلق.

0- المصريون القدماء قد روعهم مشاهدة الحيوانات المفترسة والضرر الذي يلحق بهم فاخذوا يفكرون فيها فوجدوا خير سبيل الى جلب خيرها او اتقاء شرها ان يتقربوا اليها وهم في كلتا الحالتين عبدوا الروح الخفية في الحيوان الذي يتقمصها ويرى بعض العلماء ان هذه المعبودات الحيوانية ليست الا مظهرا مجسدا او رمزا للقوة الالهية لذلك قاموا بتحنيطها. 7- لكون بعض الحيوانات تمنل الالهة كالكبش والصقر والقطة وابن اوى فربما حنطت هذه الحيوانات لتوضع في المقابر والمنازل كرمز للالهة ليحل في المكان البركة وكحماية وحرس لهم

V - وربما حنط ابن اوى رمز الالهة انوبيس، وذلك لان انوبيس كان حاميا للمومياوات ويجب ان يكون موجودا في جميع مراحل التحنيط، وربما حنط ليكون حاضرا طول هذه الفترة الطويلة بدلا عن الشخص الذي يرتدي القناع لهذا الحيوان الممثل بهيأته فتحنيطه لا يسبب تعب مائ للكاهن فيكون الحيوان المحنط حاضرا بدلا عنه. 1- الحيوانات الاليفة حنطت لكي يفاد منها في حياة ما بعد الموت مثل الغذاء والاستمتاع بها والنقل كما هو في الحياة الدنيوية. 9- ربما حنطت بعض الحيوانات لموت اصحابها لتبقى معه. • 1 - كان تحنيط الحيوانات حتى القوارض والثعابين بين ملايين الكائنات الحية التي حنطت في مصر القديمة من اجل تقديمها قرابين للالهة بل كانت الحيوانات تربى خصيصا لهذاالغرض. 


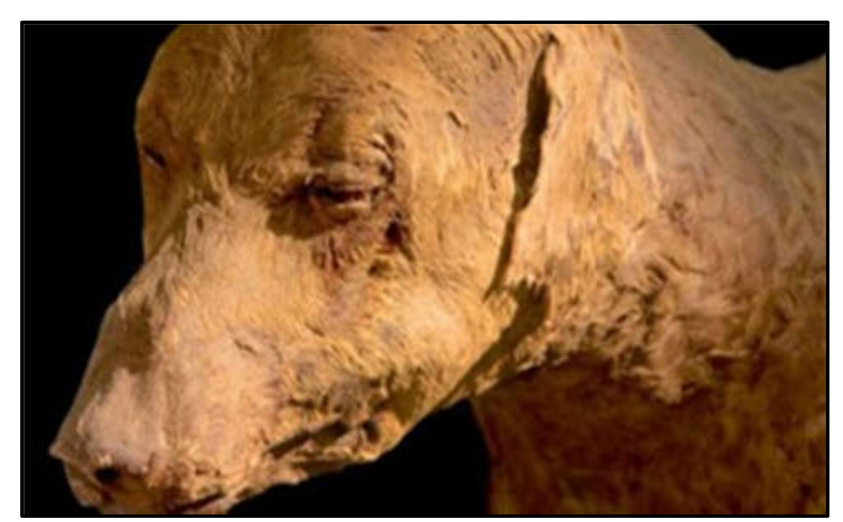

الثكل (Y) كلب محنط

www.youm7.com

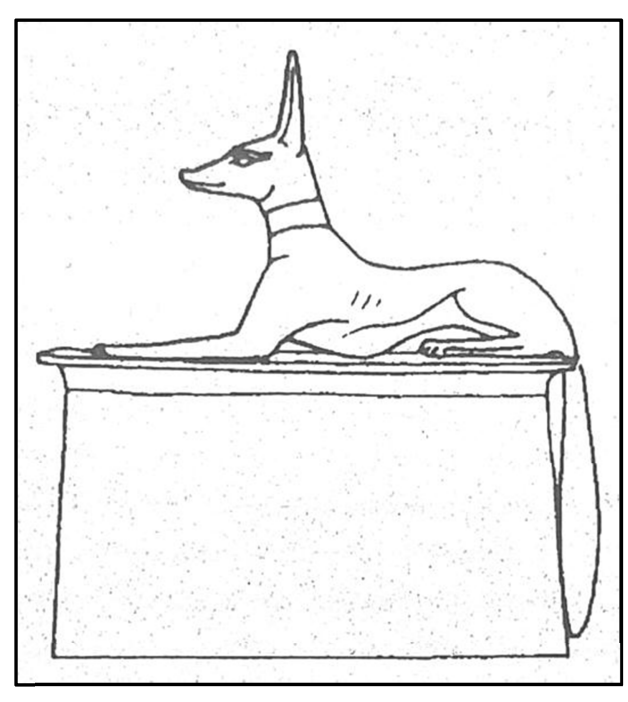

الثكل (1) الالهة انوبيس

Hart, Opcit, P.25
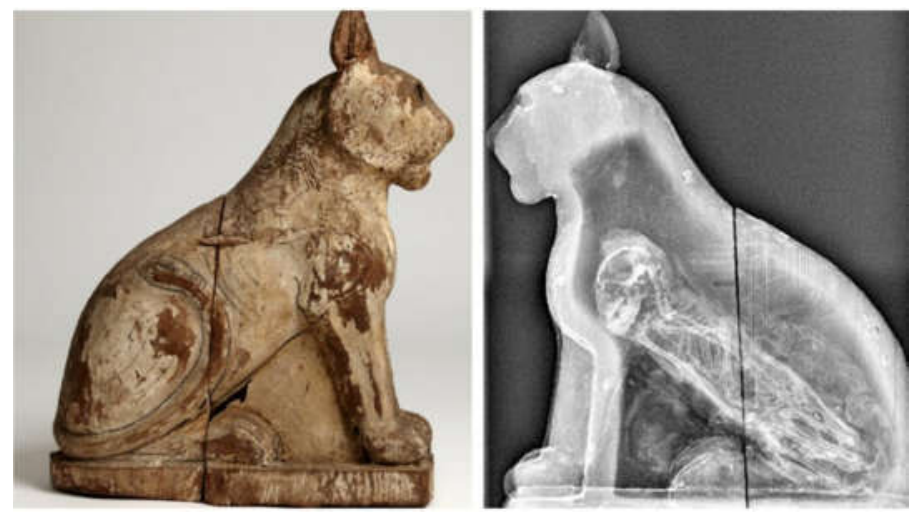

الثنكل (ع) قطة محنطة

arabic.cnn.com/entertainment

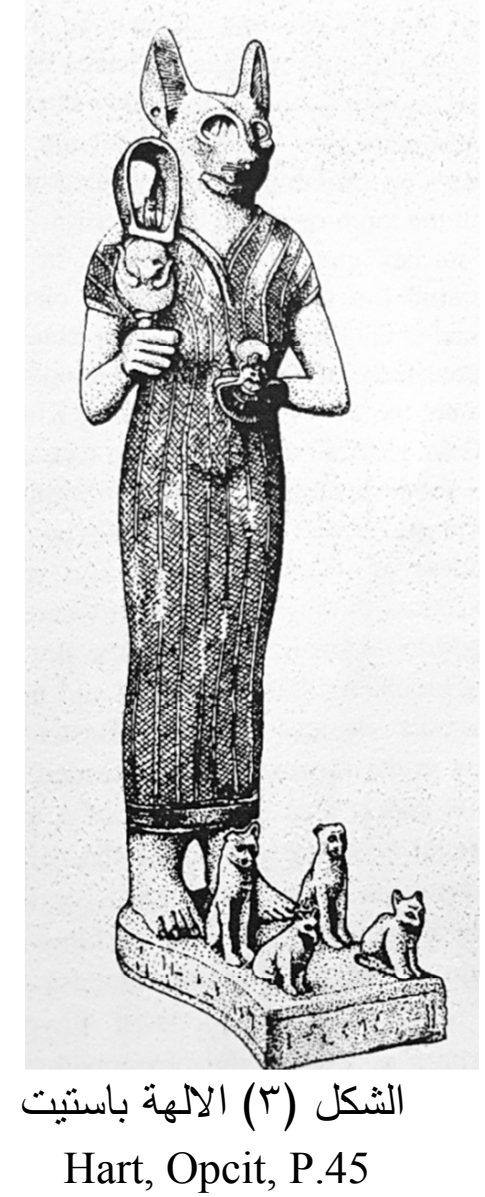

Hart, Opcit, P.45 


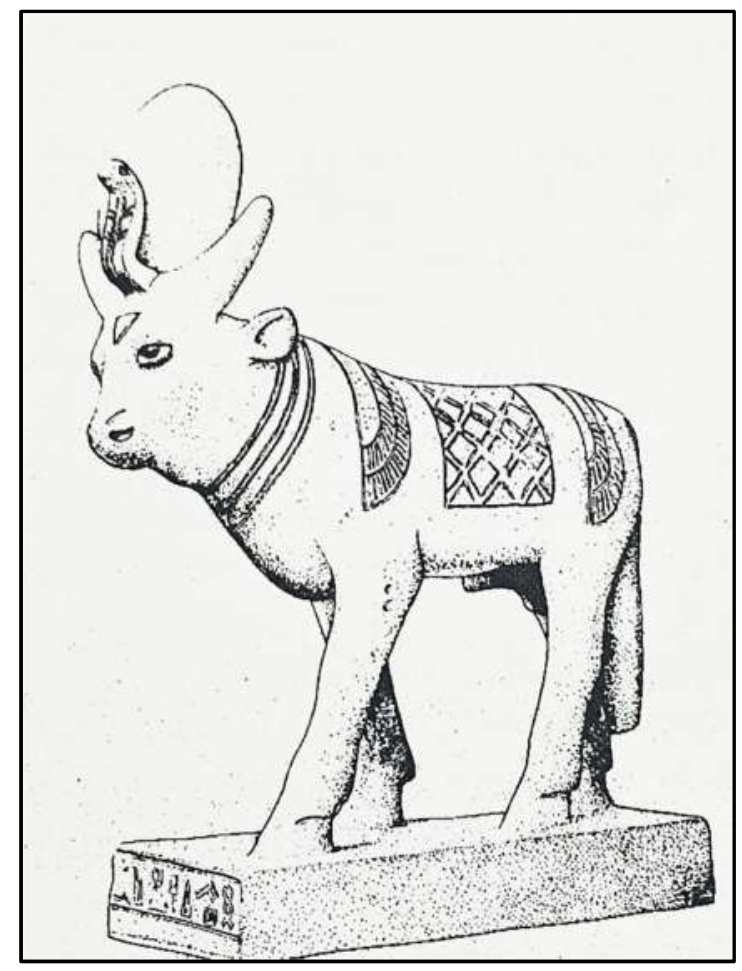

الثكل (0) : الالهة خنوم (الكبش)

Hart, Opcit, P.29

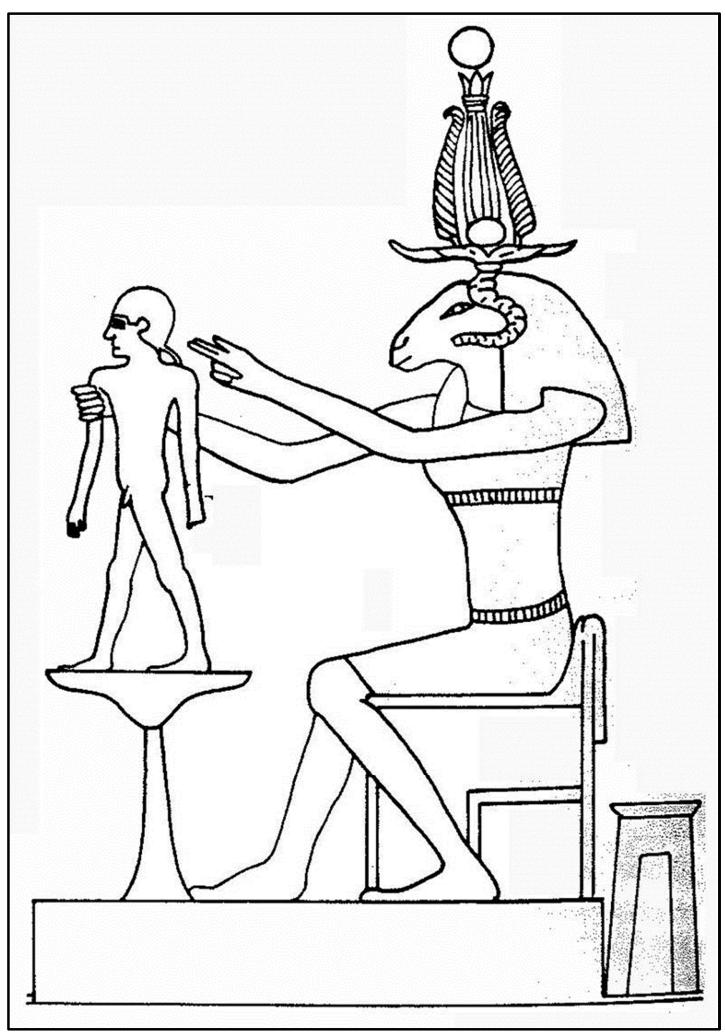

الثكل (ך) : خنوم يقوم بخلق الاطفال على عجلة الفخار www.marefa.org 

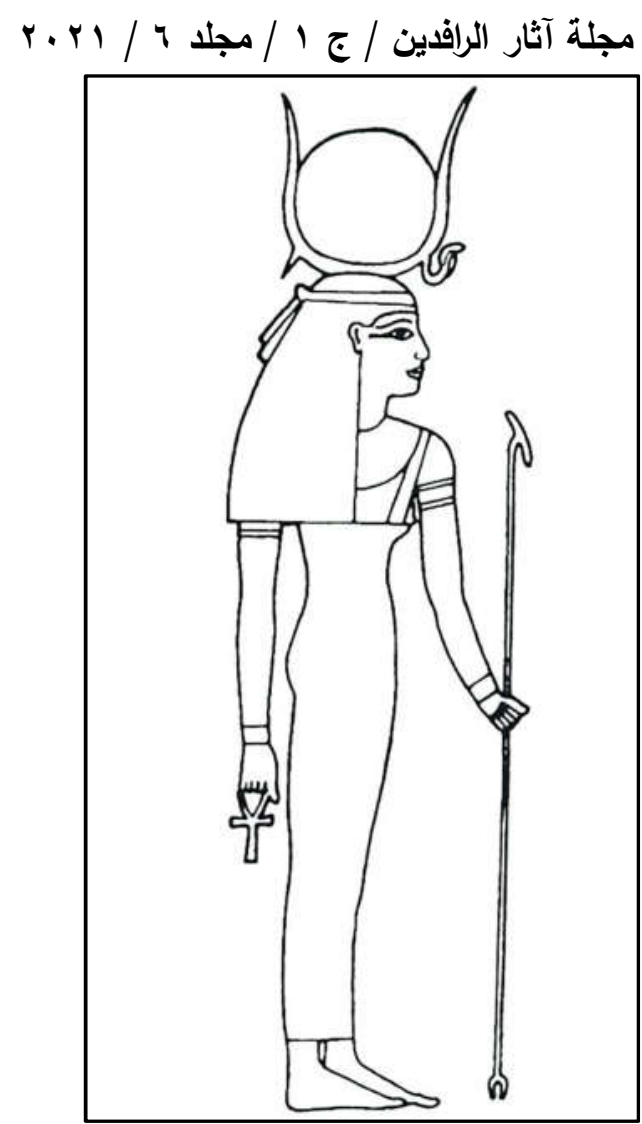

$$
\begin{gathered}
\text { الثكل (V) : الالهة حتحور (البقرة) } \\
\text { Hart, Opcit, P.62 }
\end{gathered}
$$

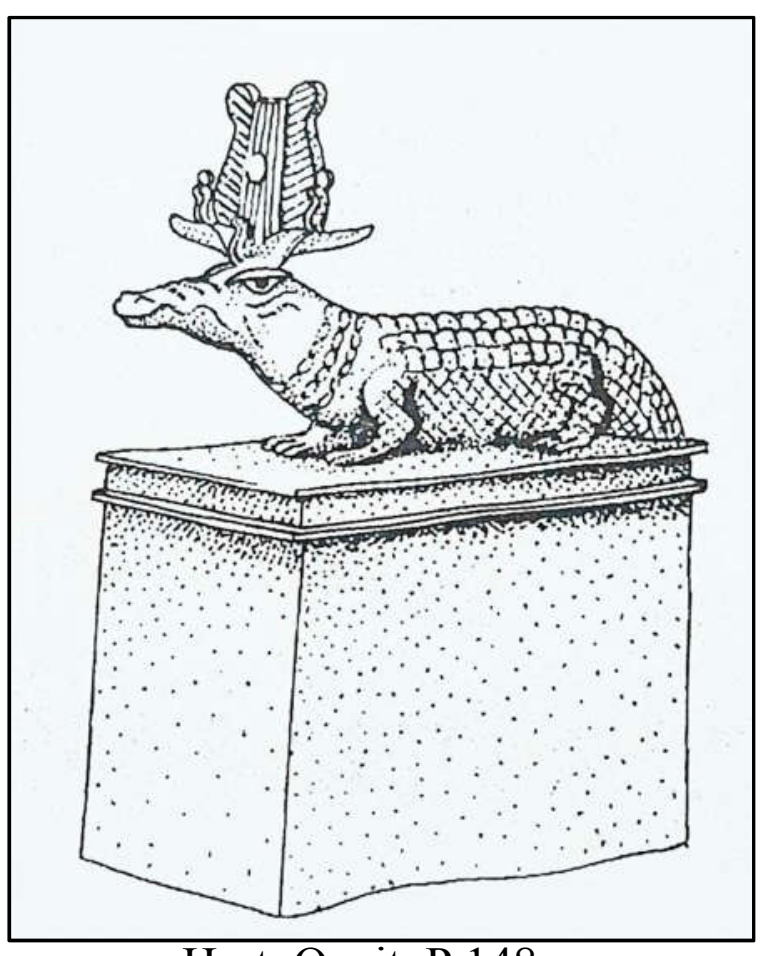

Hart, Opcit, P.148

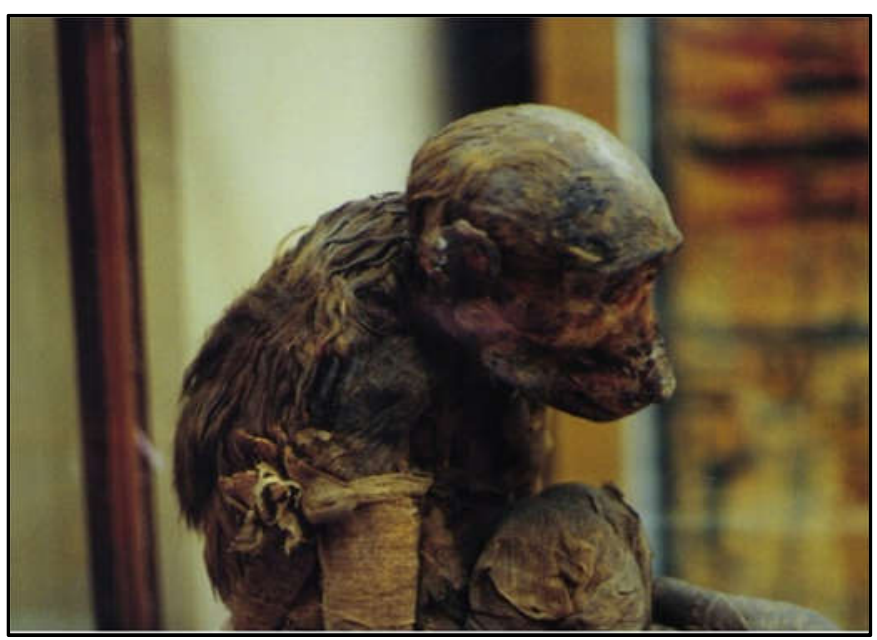

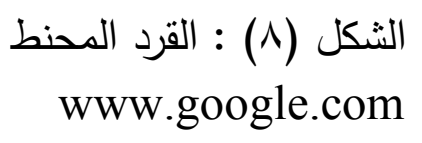


أ.م.د وسناء حسون يونس الاغا

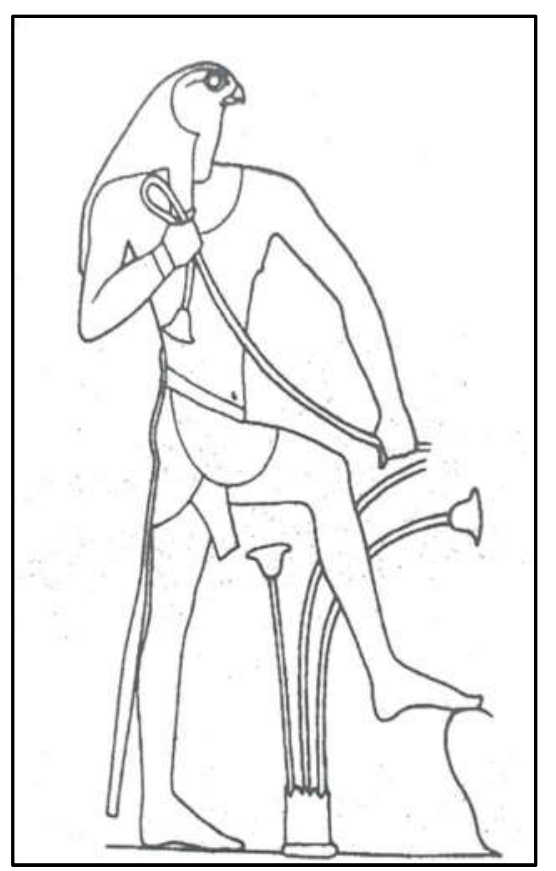

الثكل (1) (1) : الاله حورس

Hart, Opcit, P.70
دوافع تحنيط الحيوانات عند المصريين القدماء

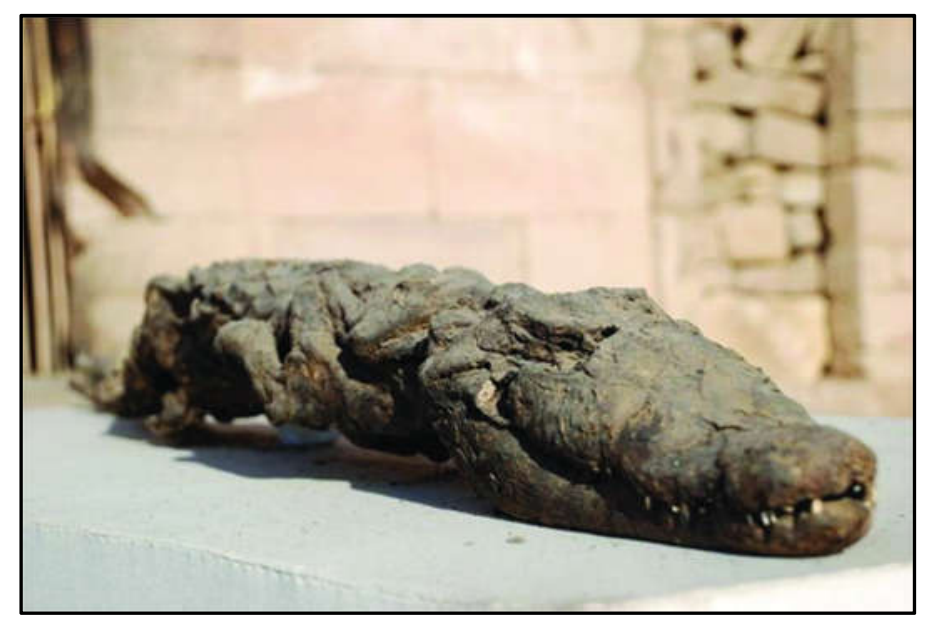

الثكل ( • () : التمساح المحنط www.albayan.ae

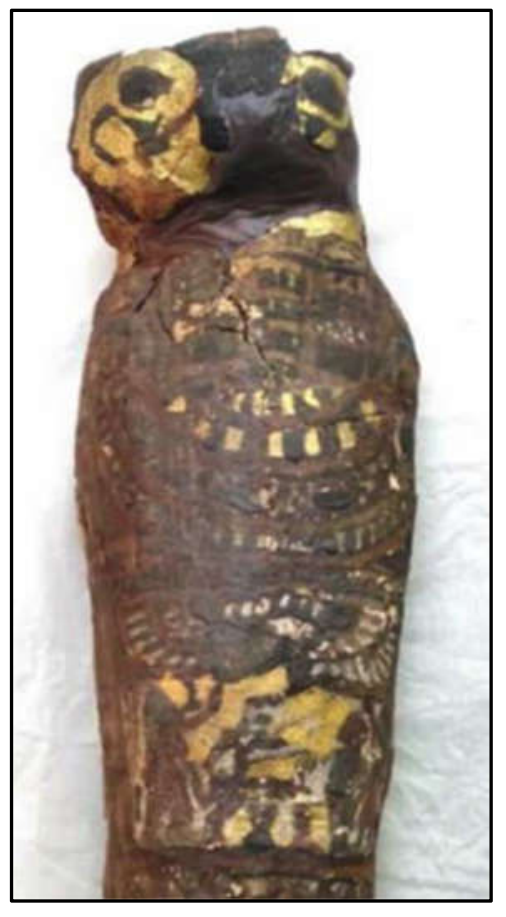

الثكل (Y) : (I) : صقر محنط

www.extranews.tv 


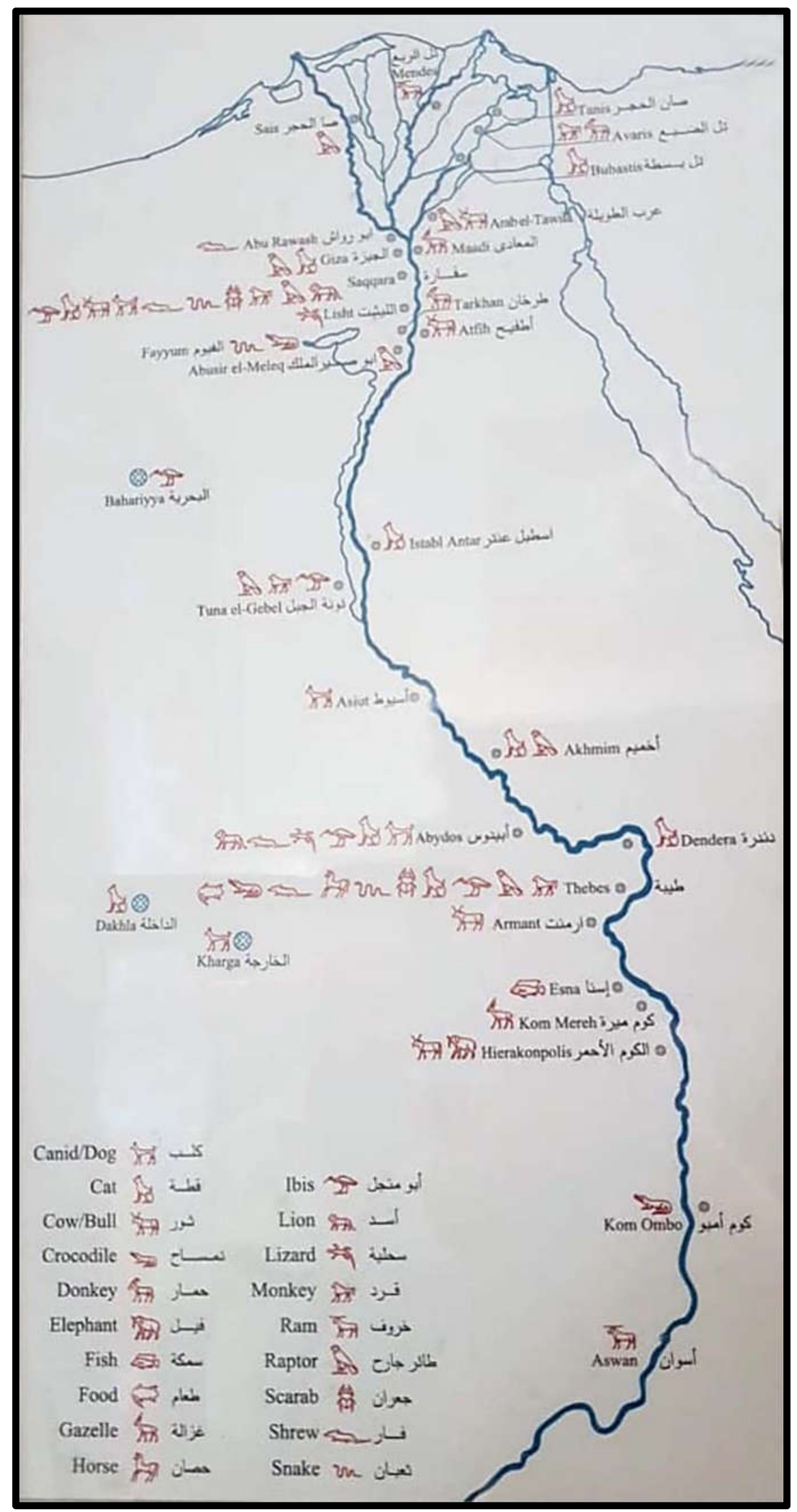

مدافن مومياوات الحيوانات في زيادة للمتحف المصري في القاهرة 
1- ابراهيم، نجيب ميخائيل ، مصر والثرق الادنى القديم، جا-1-r، مصر ، د.ت.

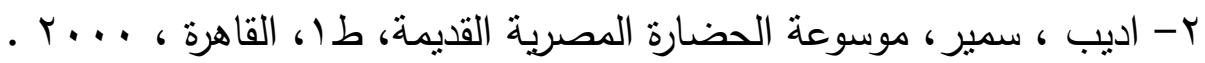

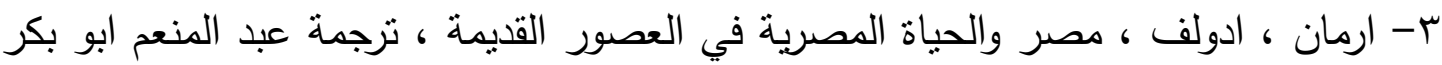
(

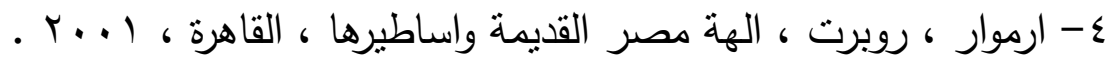

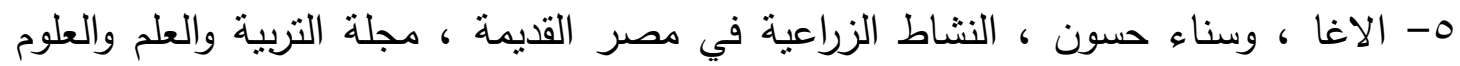

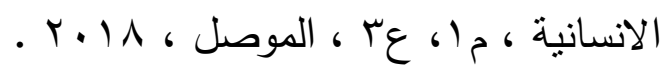

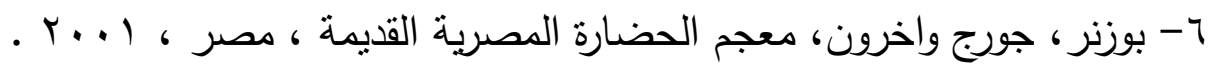

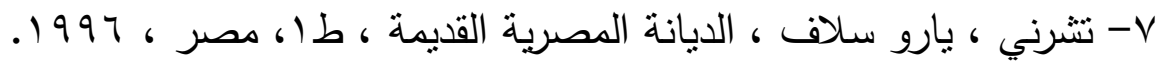

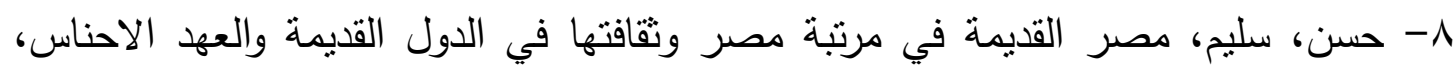

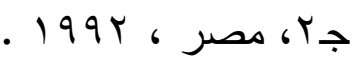
9- حواس، زاهي ، قراءة الفن المصري دليل هيروغليفي للتصوير والنحت المصري القديم،

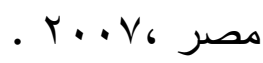
. 1 ا الخطيب ، محمد حضارة مصر القيمة ، مصر ، 1999 ـ

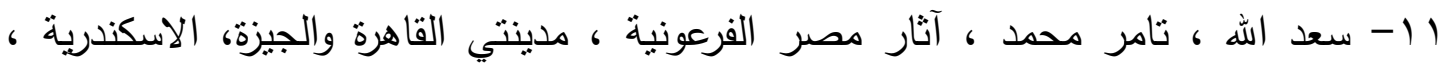
.$r \cdot 11$

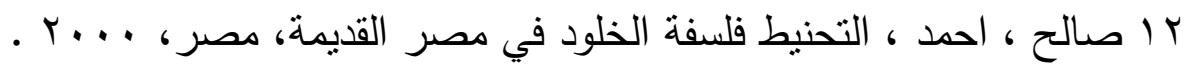

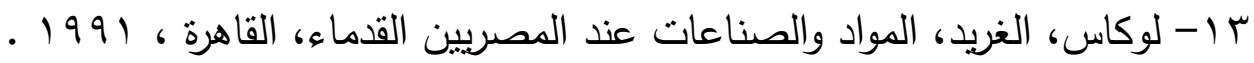

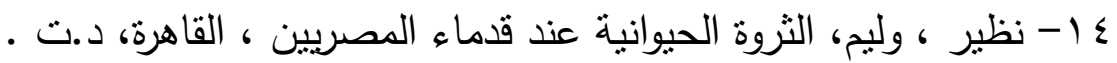

1- Aldered, Cyril. The Egyptians, London, 1961.

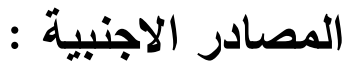

2- Hart, George, The Rutledge Dictionary of Egyptian Gods and Goddesses, $2^{\text {nd }}$, Edition, London, 2005.

3- Murray, Margaret, A. The Splndor that was Egypt, London, 1972.

4- Thompson, James C.B.A, M.Ed, Women in the Ancient World, New York, 2005 . 
1- http://www.almasryaoun,com./editor/details/830.

2- https://www.124news.tu/ar/middle-east/75532-150620.

3- $\quad$ www.bbc.com/arabic/scienceandtech/2015/11/151030-veteart=hinside-egypis, animal,mummies.

4- https://ar.m.wikepedia.org/wili القطط في مصر القديمة

${ }^{(1)}$ Story, https//www.youm7.com

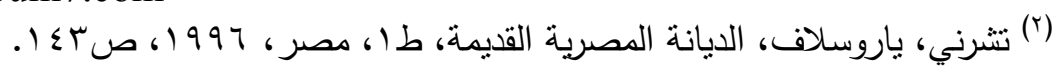

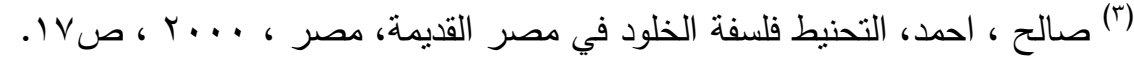

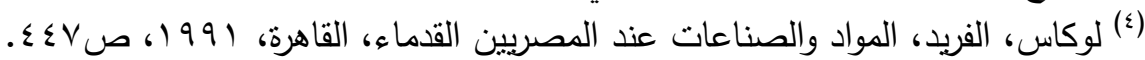

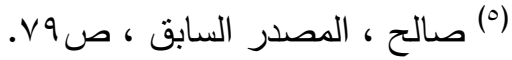

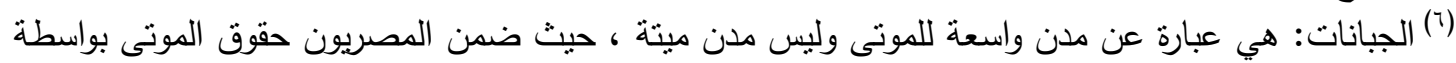

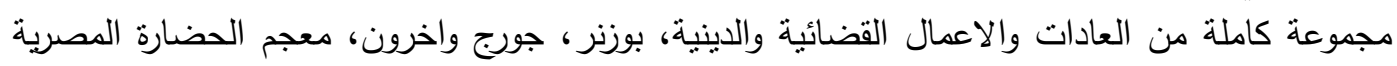

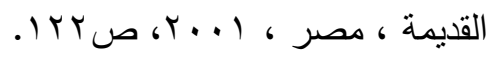
(V)

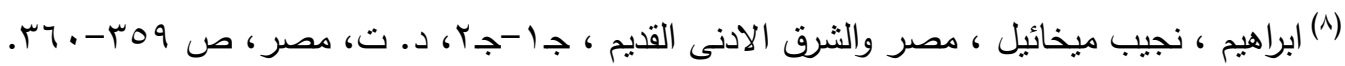

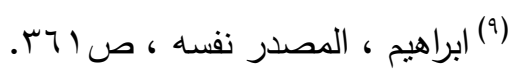

(·) ايزيس: الهة تجسد سمات الزوجة المخلصة واعظم احاسيس الامومة وهي زوجة اوزريس وام حورس ترعف بقواها السحرية وتصور دائما بقرون بقرة وقرص شمس او عرش على على رأسها.

Thompson, James C. B.A, M.Ed, Women in the Ancient World, New York, 2005, P.92-94.

('اوزريس: كان يعد اساسا اله قوى الحياة التي تعطيها المياه والزراعة والتربة وهو اله العالم الاخر وقد ارتبط

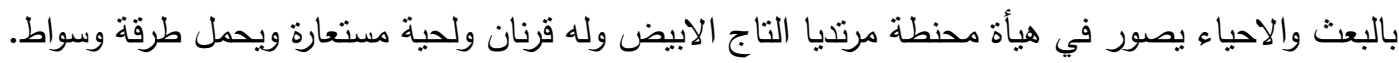

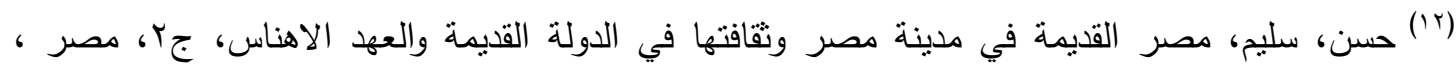

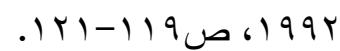

(13) Hart, George, The Rutledge Dictionary of Egyptian Godsand Goddesses, $2^{\text {nd }}$ Edition, London, 2005, P.116-119.

(؛) انوبيس : لقد ارتبط المصريون القدماء كثيرا بالاله انوبيس الذي كانوا يعتقدون انه حارس البوابة الى الاخزة وكثيرا ما كانوا يصورونه برأس كلب وجسم رجل.

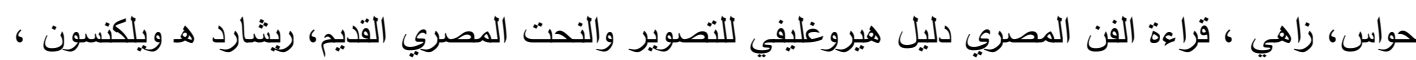

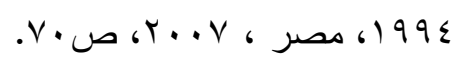

(10) تعد منطقة صقارة من اهم المناطق الاثرية في مصر ، وتبعد عن القاهرة حوالي ه ب كبلومتر واشتق اسم صقارة من اسم اله الجبانة سكر وتعد جبانة صقارة هي الجبانة الوحيدة في مصر كلها التي تضم مقابر منذ بداية التاريخ المصري القديم حتى العصرين اليوناني والروماني.

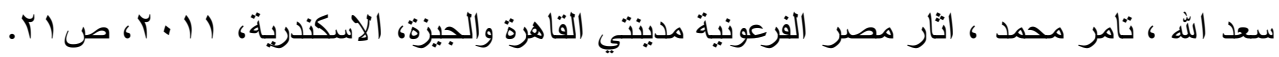


${ }^{(16)} \mathrm{https} / / / w w w .124 n e w s . t u / a r / m i d d l e-e a s t / 75532-150620$.

(v'الكتان، استعمل المصريون القدماء الكتان في اغراض شتى منها الثياب والاعفان واربطة الموتى والاشرعة والاربطة الطبية والمفروشات، وكما استعمله المصريون في لف المومياء واثواب الالهة. بوزنر، المصدر

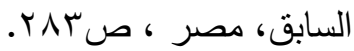

${ }^{(18)}$ http://Www.almasryaoum,com/editor/details/830

(19) باستت : الهة لها رأس قطة عبدت في بوباسنس، اصبحت الهة متعة وحامية من الارواح الثريرة وفيما بعد عبدت في شكل قطة مقدسة وكانت تحنط وتدفن.

Murray, Margaret, A, The splendor that was Egypt, London, 1972, P.95-96.

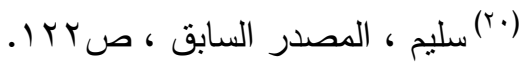

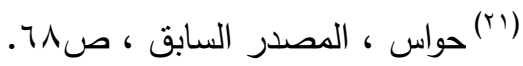

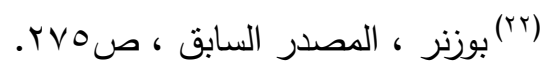

(rT)

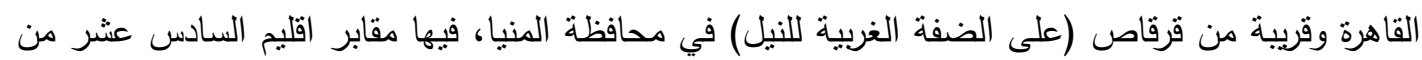
اقاليم الوجه القبلي وهي منحوتة في الصخر وجدرانها مغطاة بنقوش ملونة فوق طبقة من الملاط وعليها

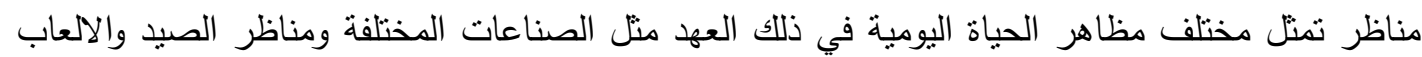

$$
\text { الرياضية والحفلات الى جانب مناظر تقديم القرابين وغيرها. }
$$

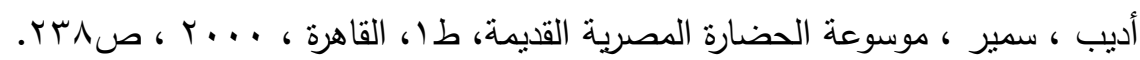

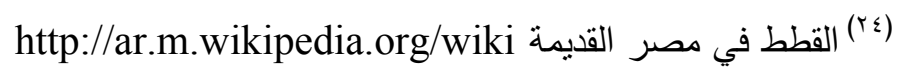

(ro) رحلة الى عالم تحنيط الحيوانات لدى قدماء المصريين ، مليسيا هوغنوم ، صحيفة علمية ، نوفيمبر ، تثرين

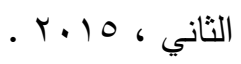

www.bbc.com/arabic/scienceandtech/2015/11/151030-vet-earth-inside-egypls, animal,mummies

$$
\begin{aligned}
& \text { (Tr) المصدر نفسها . } \\
& \text { (YY) } \\
& \text { (r^) }
\end{aligned}
$$

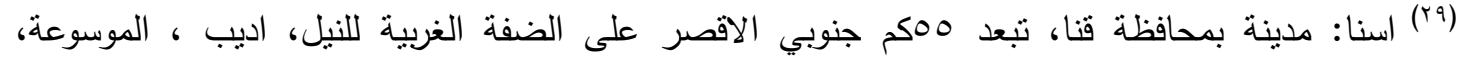

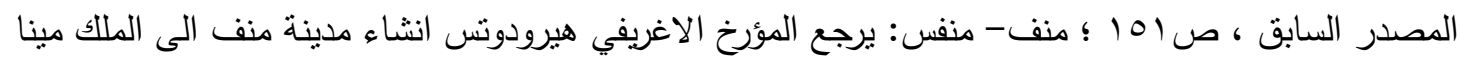

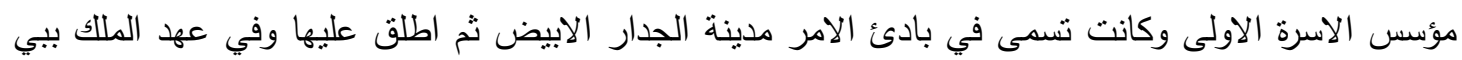

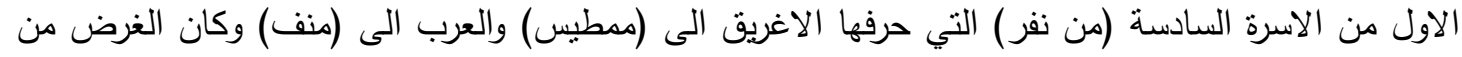

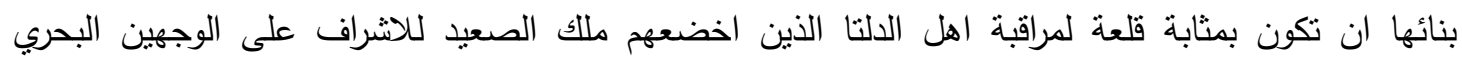

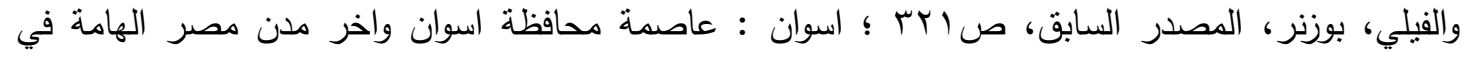

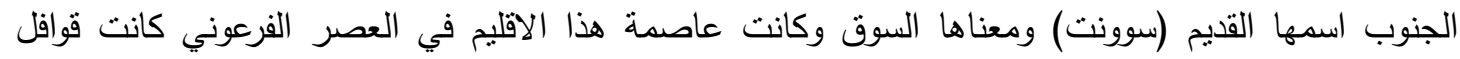

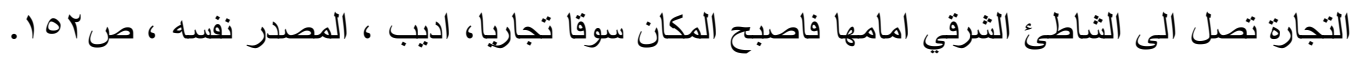

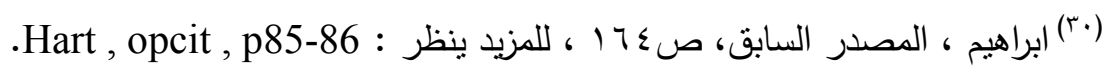

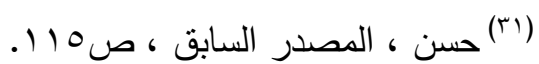

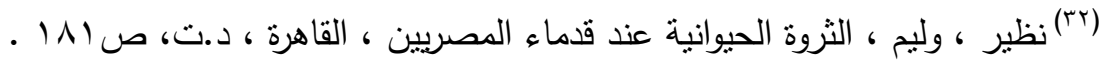


${ }^{(33)}$ Hart , Op.cit , P.85.

$$
\text { ( }
$$

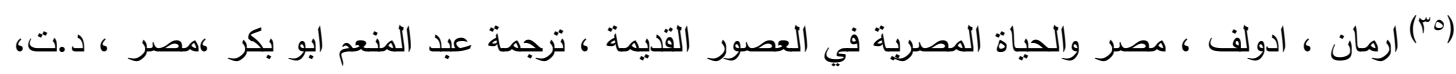

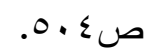

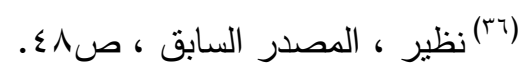

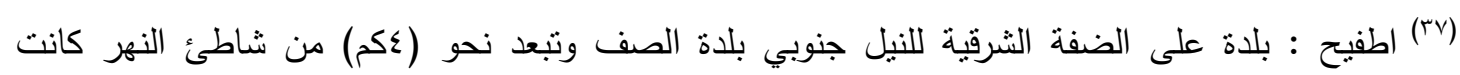
عاصمة للاقليم (rr) من اقاليم الوجه القبلي ومركزا هاما لعبادة الالهة حتحور.

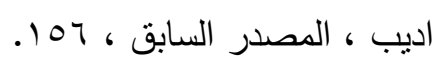

(البدارة : بلدة في محافظة اسيوط على الضفة الشرقية للنيل ، وهي اقدم حضارات العصر الحجري الحديث في الوجه القبلي وحضارة البدارة يرجع ناريخها الى عام ( . ..ـ ق.م) تقريبا ويبدو ان البداريين قد امنوا بالبعث

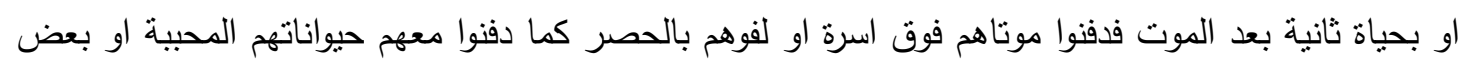

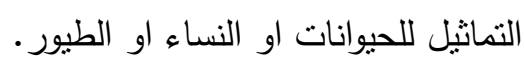

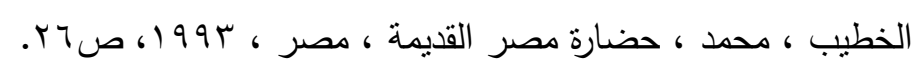

${ }^{(39)}$ Aldered, Cyril : The Egyptians, London, 1961, P.52

${ }^{(40)}$ Hart, Opcit, P.64.

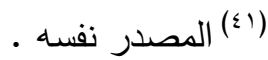

https://www.124news.tv/ar/ اخبار

${ }^{(42)}$ middle - east / 75532-150620-Hart, Opcit, P.62, Hart, ibd,P.64

(T) رع: آله الثمس لهيليوبلس وهو الجسم المرئي لثمس وقد اتخذ عدة اشكال كرجل له راس صقر مرندي قرص الثمس فوق رأسه او كعقرب او كرجل عقرب وهو اله شمس الصباح وعرف بالاله امون رع.

Hart, Opcit, P.133

(๕) شجرة الجميز : اهم الاشجار في مصر القديمة ، عثر على اخشابها منذ عصر ما قبل التاريخ في مقابر

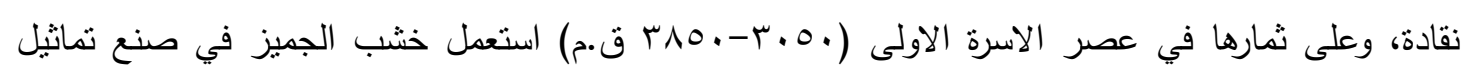

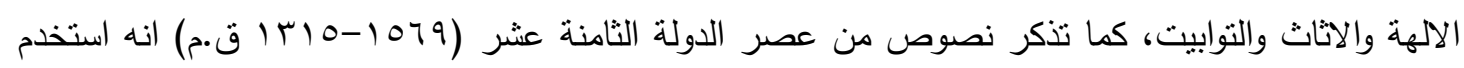
ايضا في صناعة السفن.

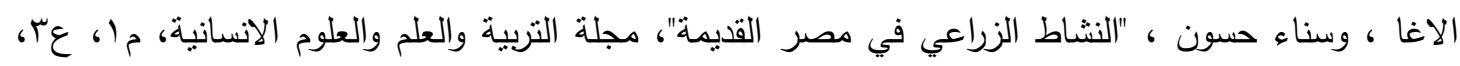

${ }^{(45)}$ Hart, Opcit, P. 62-63.

${ }^{(46)} \mathrm{htts}: / /$ www.124news.tv./ar/ اخبار/middleeast/150620

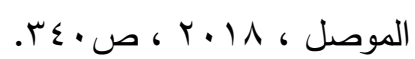

Egypt, https//www.googlecom./s/

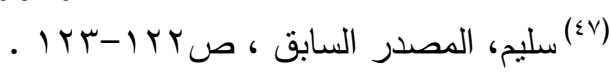

لماذا خلا المصريون القدماء في اثارهم القرد Www.alarabiyalogin

(ఓ) تحوت: اله قمري في الاصل ثم اصبح من اقوى الالهة المؤثرة اله الحكمة والكتابة وهو مخترع الهيروغليفية

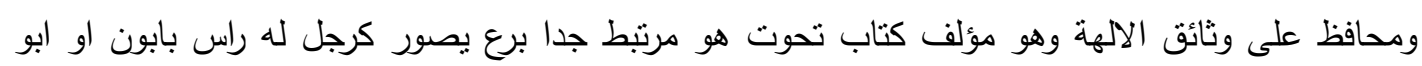

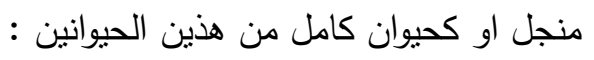

${ }^{(49)}$ Hart, Opcit, P.158.

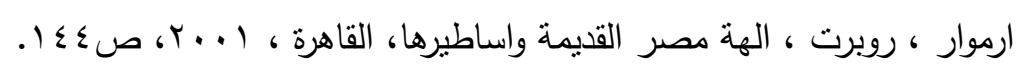




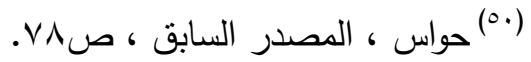

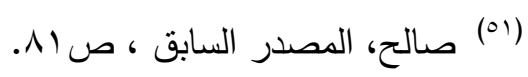

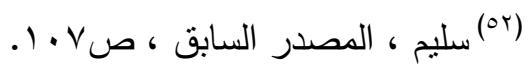

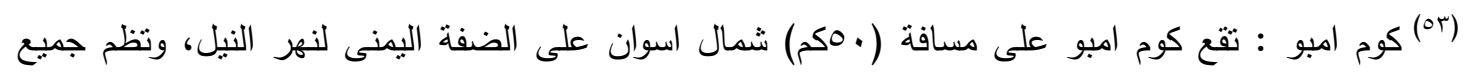

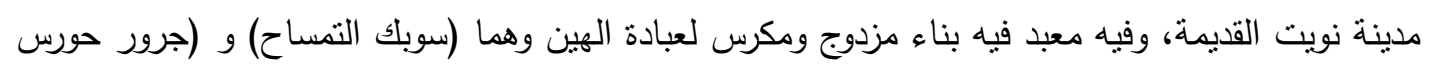

$$
\begin{aligned}
& \text { الكبير ذو راس الصقر ). }
\end{aligned}
$$

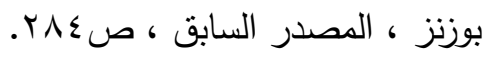

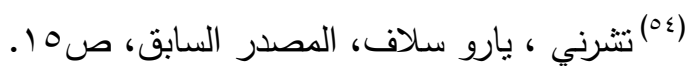

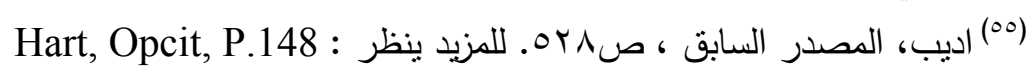

${ }^{(57)}$ Hart, Opcit, P.70-76.

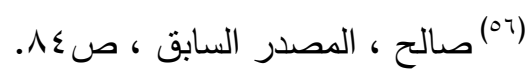

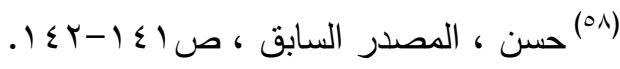

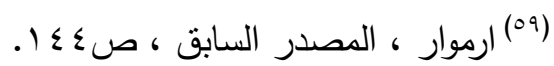




Contents

\begin{tabular}{|c|c|c|}
\hline Page & Research Name & $\overline{\text { Subject }}$ \\
\hline 1 & Prof. Khalid Salim Ismael & $\begin{array}{r}\text { Preface } \\
\end{array}$ \\
\hline $3-19$ & $\begin{array}{l}\text { Oday Abdulwahhab Al.Noamy } \\
\text { Prof. Khalid Salim Ismael }\end{array}$ & $\begin{array}{l}\text { From Epics of Kings in the Second and } \\
\text { First Millennium B.C. - An Analytical } \\
\text { Study }\end{array}$ \\
\hline $21-44$ & Prof. Dr. Farouk Ismail & The Ransom in Akkadian Texts \\
\hline $45-70$ & $\begin{array}{c}\text { Reem Mohammad Salih } \\
\text { Prof. Dr. Safwan Sami Saeed }\end{array}$ & $\begin{array}{l}\text { Assyrian's Concerns of Fear and Anxiety } \\
\text { Regarding Demons and Evil Spirits }\end{array}$ \\
\hline 71-91 & $\begin{array}{c}\text { Sondos Ali Hammadi } \\
\text { Prof. Dr. Yasser Al-Mashhadani }\end{array}$ & Sivas City before the Seljuk Rule \\
\hline $93-114$ & $\begin{array}{l}\text { Assist. Prof. Dr. Mohammed Kamil Rokan } \\
\text { Dr. Jumaa Heraz Al-Talbe }\end{array}$ & $\begin{array}{c}\text { Russian Excavations in Sinjar Region, } \\
\text { Northern Iraq }\end{array}$ \\
\hline $115-137$ & $\begin{array}{c}\text { Mustafa Ahmed Ali Al-Samarrai } \\
\text { Assist. Prof. Dr. Yasmine Abdul Karim } \\
\text { Mohammed Ali }\end{array}$ & $\begin{array}{c}\text { Residential Houses from the Moncorn } \\
\text { Assyrian Period (911-612) BC. M- } \\
\text { Elected Sites from the Makhul Dam } \\
\text { Project Area }\end{array}$ \\
\hline $139-164$ & $\begin{array}{l}\text { Falih Ghdwi Noman Al-Shammary } \\
\text { Assist. Prof. Dr. Haider Farhan Hussein } \\
\text { Al-Subaihawi }\end{array}$ & Heritage Mosques in Sinjar City \\
\hline $165-185$ & Assist Prof. Dr.Hussein .Y.Hazim & $\begin{array}{l}\text { Carbonated Grains and it's Role in } \\
\text { Archaeological Detection during } \\
\text { Prehistory - An Analytical Study }\end{array}$ \\
\hline $187-211$ & $\begin{array}{l}\text { Ashraf Aziz Abdul - Karim Al_Halay bik } \\
\text { Dr. Shakeeb Rashid Bashir Al- Fattah }\end{array}$ & $\begin{array}{l}\text { The Efforts of Scientific Families in } \\
\text { Building Schools and Teaching (Ibn Al- } \\
\text { Jawzi Family as a Model) }\end{array}$ \\
\hline 213-233 & $\begin{array}{c}\text { Asst. prof. Dr. Wasnaa Hasoun Younis } \\
\text { al-Aghaa }\end{array}$ & $\begin{array}{l}\text { Motives behind the Mummification of } \\
\text { Animals by the Ancient Egyptians }\end{array}$ \\
\hline $235-261$ & Dr. Aram J. Hassan Hamawand & $\begin{array}{l}\text { The Brick Completion Receipts from the } \\
\text { City of Pekasi, "Till Abu-Antik" } \\
\text { "An Analytical Study of Unpublished } \\
\text { Cuneiform Texts" } \\
\end{array}$ \\
\hline 263-279 & $\begin{array}{l}\text { Dr. Mohanad Khalaf Jamen Al shamari } \\
\text { Hanan Abdul-Hamzah Beuawe }\end{array}$ & $\begin{array}{l}\text { Unpublished Economic Texts from Ur III } \\
\text { Dynasty }\end{array}$ \\
\hline 281-302 & $\begin{array}{c}\text { Muthanna Saadoun Dhafer Al-Hindawi } \\
\text { Dr. Mahmoud Ibrahim Hussien } \\
\text { Dr. Dalia Mohamed El-Sayed } \\
\end{array}$ & $\begin{array}{l}\text { Demons and Evil Spirits in Ancient Iraq } \\
\text { in Light of Cuneiform Texts }\end{array}$ \\
\hline
\end{tabular}


12- The original research papers submitted to the magazine are not returned to their owners, whether published or not.

13- Tables and figures are numbered in a row according to their appearance in the research, provided with titles, submitted with separate papers, blueprints are submitted in black ink and images to be in high resolution.

14- The marginal numbers are written in parentheses and are presented in series at the end of the research.

15- The full source name is indicated in the margin, with the abbreviated source in parentheses at the end of the margin.

16- The researcher is responsible for correcting the linguistic and typographical errors in his research.

17- The magazine operates according to self-funding. Therefore, the researcher bears the publication fees of $(100,000)$ one hundred thousand Iraqi dinars.

18- Each researcher shall be provided with one copy of his research. As for the full copy of the journal, it is requested from the magazine's secretariat and a price is determined by the Editorial Board.

19- The papers should be sent to the journal e-mail:

uom.atharalrafedain@gmail.com 


\section{Publishing rules in Athar Al-Rafedain Journal (AARJ):}

1- The journal accepts scientific research that falls in specializations:

- Ancient Archaeology and Islamic Archaeology .

- Ancient languages with their dialects and comparative studies.

- Cuneiform Inscriptions and ancient lines.

- Historical and cultural studies

- Archaeological geology.

- Archaeological survey techniques.

- Anthropological studies.

- Conservation and restoration.

2- Research papers shall be submitted to the magazine in both Arabic and English.

3- The research shall be printed on (A4) paper, word-2010 system, with double spaces between lines, Simplified Arabic font for Arabic language, Times New Roman for English language, delivered on $\mathrm{CD}$, and in two paper based copies.

4- The title of the research should be printed in the middle of the page, followed by the name of the researcher, his academic degree, his full work address, and e-mail.

5- The research should contain an abstract in Arabic and English languages, it shouldn't exceed (100) words.

6- The abstract of the research in English contains the title of the research, the name of the researcher, his academic degree, his full workplace, and his e-mail.

7- The research must include keywords related to the title of the research and its content.

8- That the research was not previously published or was submitted to obtain a degree or is derived from the intellectual property of another researcher, and the researcher must undertake this in writing when submitting it for publication.

9- The researcher is obliged to follow the correct scientific foundations in his research.

10- The researcher is obligated to amend his research terms to suit the experts 'suggestions and the method of publishing in the journal.

11- The number of research pages does not exceed (25) pages, and in case of exceeding the required number, the researcher shall pay an additional amount for each additional page. 


\author{
Arabic Language Expert \\ Dr. Maan Yahya Mohammed \\ Dep. Of Arabic Language /College of Arts / University of Mosul
}

\author{
English Language Expert \\ Assist. Lect. Ammar Ahmed Mahmood \\ Dep. Of Translation Language / College of Arts / University of Mosul
}

Design Cover

Dr. Amer Al-Jumaili 


\title{
$\underline{\text { Editorial Board }}$
}

\author{
Prof. Khalid Salim Ismael \\ Editor-in-Chief
}

\section{Assist Prof. Hassanein Haydar Abdlwahed \\ Managing Editor}

\section{Members}

Prof. Elizabeth Stone

Prof. Adeileid Otto

Prof. Walther Sallaberger

Prof. Nicolo Marchetti

Prof. Hudeeb Hayawi Abdulkareem

Prof. Jawad Matar Almosawi

Prof. Rafah Jasim Hammadi

Prof. Abel Hashim Ali

Assist Prof. Yasamin Abdulkareem Mohammed Ali

Assist Prof. Vyan Muafak Rasheed

Assist Prof. Hani Abdulghani Abdullah 



\section{Journal}

\section{Athar Al-Rafedain}

Accredited Scientific Journal

It Search's in Archaeology of Iraq and Ancient Near East

Published by College of Archaeology - University of Mosul

E-Mail: uom.atharalrafedain@gmail.com

Vol.6 / No.1

Rejab. 1442 A.H. / Feb. 2021 A.D. 

University of Mosuil College of Archaedogy

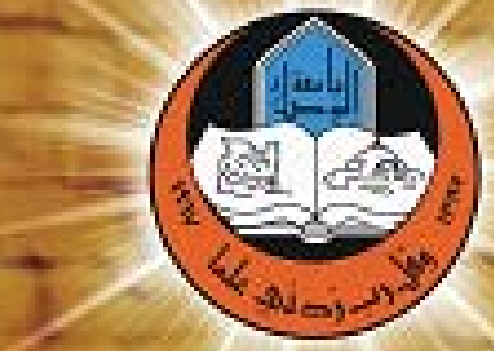

Ministry of Higher

Education and Sclentific

Research

ISSN $2304-103 X$

【RPG|

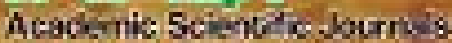

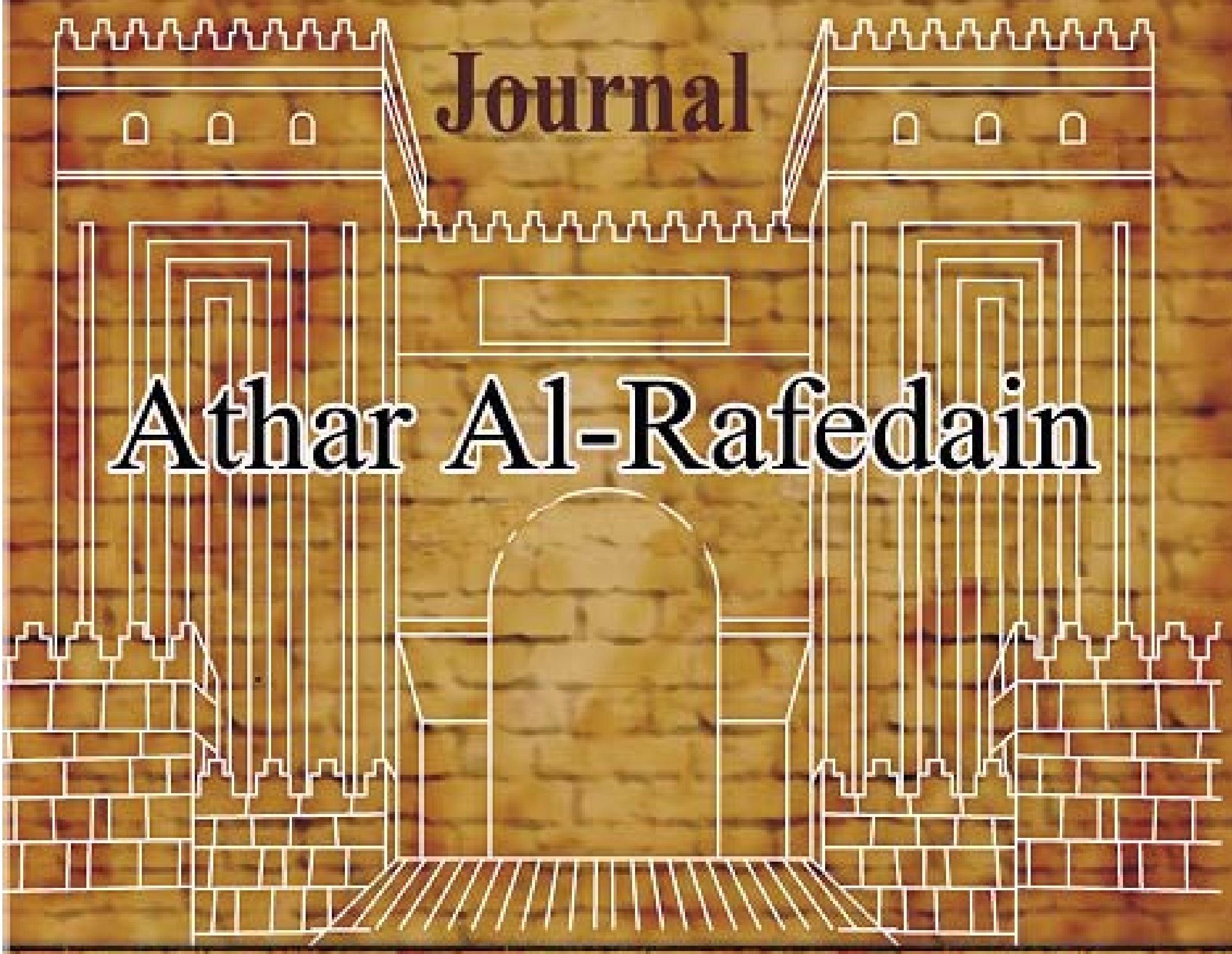

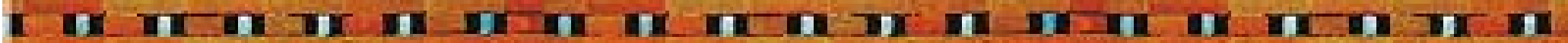

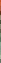

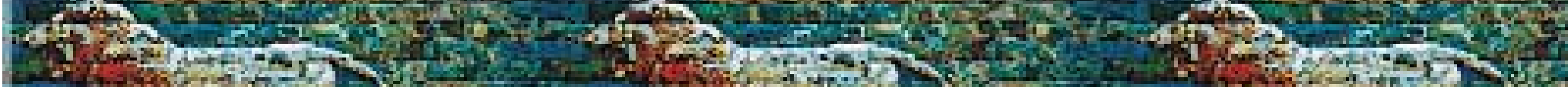

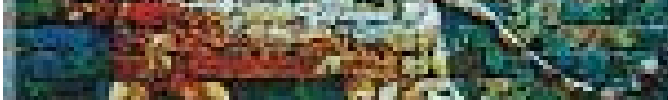
W.

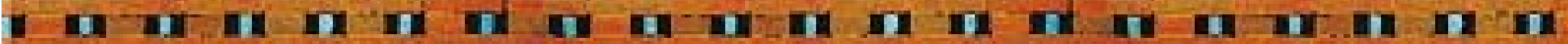

Accredited Scientific Journal it Search's in Archaeology of Iraq and Ancient Near East

Published College of Archaeology - University of Mosul / Vol.6/ No.1 / 1442 A.H. / 2021 A.D. 